\title{
NOCTURNAL LIGHT AND TEMPERATURE INFLUENCES ON \\ NECROPHAGOUS, CARRION-ASSOCIATING BLOW FLY SPECIES \\ (DIPTERA: CALLIPHORIDAE) OF FORENSIC IMPORTANCE IN CENTRAL \\ TEXAS
}

\author{
A Thesis \\ by \\ RYAN SCOTT KIRKPATRICK \\ Submitted to the Office of Graduate Studies of \\ Texas A\&M University \\ in partial fulfillment of the requirements for the degree of \\ MASTER OF SCIENCE
}

August 2004

Major Subject: Entomology 


\title{
NOCTURNAL LIGHT AND TEMPERATURE INFLUENCES ON \\ NECROPHAGOUS, CARRION-ASSOCIATING BLOW FLY SPECIES \\ (DIPTERA: CALLIPHORIDAE) OF FORENSIC IMPORTANCE IN CENTRAL \\ TEXAS
}

\author{
A Thesis \\ by \\ RYAN SCOTT KIRKPATRICK
}

Submitted to Texas A\&M University

in partial fulfillment of the requirements

for the degree of

MASTER OF SCIENCE

Approved as to style and content by:

Jimmy K. Olson

(Chair of Committee)

Leon H. Russell Jr.

(Member)

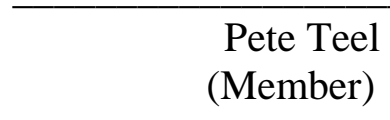

Kevin Heinz

(Head of Department)

August 2004

Major Subject: Entomology 


\begin{abstract}
Nocturnal Light and Temperature Influences on Necrophagous, Carrion-Associating Blow Fly Species (Diptera: Calliphoridae) of Forensic Importance in Central Texas. (August 2004)

\author{
Ryan Scott Kirkpatrick, B.S., Texas A\&M University \\ Chair of Advisory Committee: Dr. Jimmy Karl Olson
}

It is commonly thought that blow flies are nocturnally inactive. Blowflies are often important in helping to estimate post mortem intervals (PMI) for corpses found at death scenes. If blow flies oviposit during nocturnal hours, there could possibly be up to 12-hour discrepancies for estimates of PMI.

Two blow fly species, Phaenicia eximia (Wiedemann) and Cochliomyia macellaria (F.), oviposited nocturnally on ground beef baits in 2003, during the onset of low-atmospheric pressure (an air mass with lower atmospheric pressure than that of the air surrounding it) at rural study sites near Snook (Burleson County), Texas, under artificial lighting of at least 1500 footcandles when temperatures were at $26^{\circ} \mathrm{C}$ or higher. Trials conducted under similar conditions during the same year without a low-pressure system moving into the area resulted in no nocturnal blow fly oviposition.

Nocturnal blow fly oviposition went undetected once low-atmospheric pressure systems settled into the study area, irrespective of temperature and lighting conditions. Thus, this study illustrates that there is a connection between the onset of low- 
atmospheric pressure and nocturnal blow fly oviposition on baits under artificial lighting of 1500 footcandles or more when temperatures are $26^{\circ} \mathrm{C}$ or above.

After concluding 2003 experiments, statistical analyses supplied evidence that woodland habitat was more favorable for blow fly oviposition than prairieland habitat throughout the 2003 study, irrespective of species or time of year. Furthermore, statistical analyses conducted on nocturnal and diurnal temperature ranges furnished evidence to support the hypothesis that 2003 nocturnal temperatures had more of an effect on daily ovipositing than diurnal temperatures for P. eximia and Cynomyopsis cadaverina (Robineau-Desvoidy). 


\section{TABLE OF CONTENTS}

Page

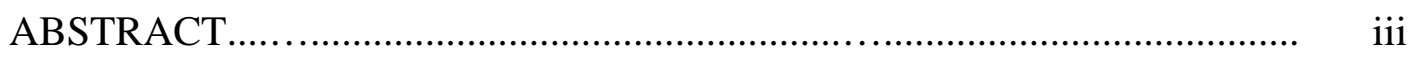

TABLE OF CONTENTS................................................................... v

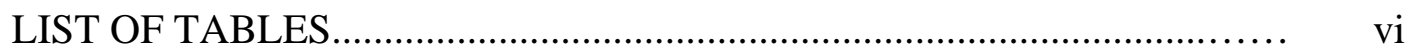

LIST OF FIGURES...................................................................... viii

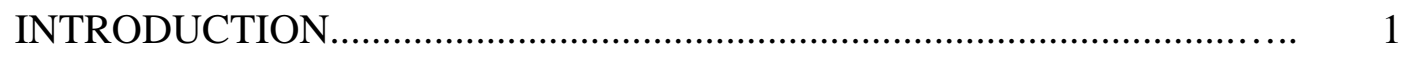

LITERATURE REVIEW..................................................................

$\begin{array}{lll}\text { Evidence Supporting Nocturnal Oviposition by Blow Flies... } & 7\end{array}$ Evidence Against Nocturnal Oviposition by Blow Flies....... 8

Problem Summary............................................................ 9

MATERIALS AND METHODS.............................................................. 11

Study Site Locations.................................... 11

Nocturnal Blow Fly Oviposition Study............................ 14

Seasonal Blow Fly Oviposition Study ....................... 21

Seasonal Blow Fly Oviposition Study Statistical Analysis.... 22

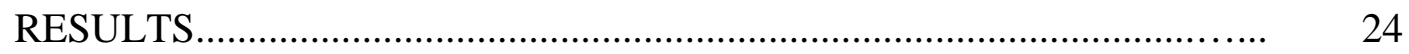

Nocturnal Blow Fly Oviposition Activity....................... 24

Seasonal Blow Fly Oviposition Activity.................... 27

Statistical Analysis of Diurnal Blow Fly Activity............ 33

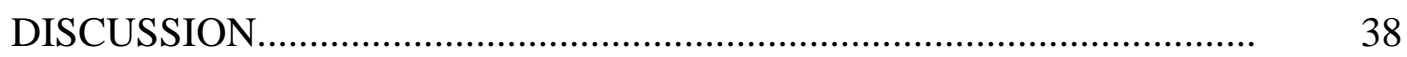

Nocturnal Oviposition by Blow Flies................................ 38

Seasonal Blow Fly Activity............................... $\quad 40$

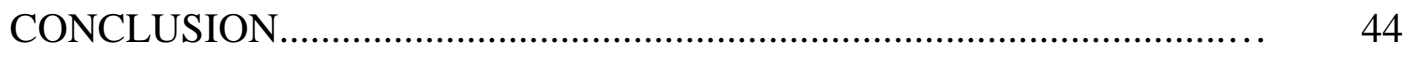

REFERENCES CITED..........................................................................

VITA 


\section{LIST OF TABLES}

Table

Page

1 Seasonal and environmental data for blow fly species that oviposited nocturnally under artificial lighting conditions during the 2003 nocturnal oviposition study near Snook (Burleson County), Texas

2 Climate data during the 2003 June 5-20 trial for the blow fly nocturnal oviposition research site near Snook (Burleson County), Texas, when nocturnal oviposition occurred under artificial lighting

3 Climate data during the 2003 June 21-August 14 trial for the nocturnal blow fly oviposition research site near Snook (Burleson County), Texas, when nocturnal oviposition occurred under artificial lighting.......

4 Diurnal blow fly egg-laying activity at the Snook (Burleson County), Texas, experimental sites during the 2003 June 5-20 experiments...

5 Diurnal blow fly egg-laying activity at the Snook (Burleson County), Texas, experimental sites during the 2003 June 21-August 14 experiments.

6 Diurnal blow fly egg-laying activity at the Snook (Burleson County), Texas, experimental sites during the 2003 October 20-30 experiments...

7 Diurnal blow fly egg-laying activity at the Snook (Burleson County), Texas, experimental sites during the 2003 December 1-10 experiments.....

8 Diurnal rainfall and diurnal temperature fluctuations for the blow fly oviposition research study site area near Snook (Burleson County), Texas, during the 2003 June 5-20 experiments

9 Diurnal rainfall and diurnal temperature fluctuations for the blow fly oviposition research study site area near Snook (Burleson County), Texas, during the 2003 June 21-August 14 experiments

10 Diurnal rainfall and diurnal temperature fluctuations for the blow fly oviposition research study site area near Snook (Burleson County), Texas, during the 2003 October 20-30 experiments 


\section{LIST OF TABLES CONTINUED}

Table

Page

11 Diurnal rainfall and diurnal temperature fluctuations for the blow fly oviposition research study site area near Snook (Burleson County), Texas, during the 2003 December 1-10 experiments...

12 Binary logistic regression analysis results giving predicted probabilities for seasonal blow fly species oviposition activity at prairieland and woodland habitat study sites near Snook (Burleson

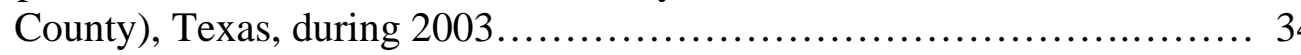

13 Predicted probabilities for nocturnal temperature effects on diurnal ovipositing by blow fly species at the 2003 research study site near Snook (Burleson County), Texas................................... 36 


\section{LIST OF FIGURES}

Figure

Page

1 Diagram of the 2003 rural nocturnal blow fly oviposition research study site near Snook (Burleson County), Texas (scale: $1 \mathrm{~cm}=7.6 \mathrm{~m}$ )........... 12

2 Prairieland habitat study site used for the nocturnal blow fly oviposition study conducted near Snook (Burleson County), Texas, in 2003.............. 13

3 Woodland habitat study site used for the nocturnal blow fly oviposition study conducted near Snook (Burleson County), Texas, in 2003............ 13

4 Individual artificial lighting in prairieland (A) and woodland (B) habitats for 2003 nocturnal oviposition experiments near Snook (Burleson County), Texas................................................. 15

5 Artificial lighting system at the 2003 woodland habitat experimental site near Snook (Burleson County), Texas................................. 15

6 Artificial lighting system at the 2003 prairieland habitat experimental site near Snook (Burleson County), Texas................................ 16

7 An example of plastic, modified, Bioquip ${ }^{\circledR}$ rearing containers in which blow fly eggs and larva were reared for 2003 nocturnal oviposition experiments near0 Snook (Burleson County), Texas...................... 19 


\section{INTRODUCTION}

Forensic Entomology is defined as any aspect of the study of insects and their arthropod counterparts that interact with legal matters (Byrd \& Castner 2001, Catts \& Haskell 1990, Kirkpatrick \& Olson 2001). The earliest recorded use of arthropods used in legal matters was an investigation in $13^{\text {th }}$ Century China. In 1265 AD, magistrate Sung Tzu documented in his book, " The Washing Away of Wrongs "a case in which he investigated a slashing murder in a Chinese village using forensic science. After questioning the village residents, Sung Tzu had all of the villagers bring their sickles to one spot and lay them before all in the village to see. Flies congregated on the sickle with traces of blood and tissue. Confronted with the evidence before them, the perpetrator confessed to the crime (Byrd \& Castner 2001, Catts \& Haskell 1990, Tenorio et al. 2003).

Forensic Entomology is a broad field where arthropods, science, and the judicial system interact with one another (Catts \& Haskell 1990). Entomologists are increasingly being called upon to apply their expertise and knowledge in criminal and civil proceedings (Catts \& Haskell 1990). In this respect, there are three basic areas of entomology that most commonly have a forensic component associated with them: urban entomology, stored products entomology, and medicolegal entomology (Byrd \& Castner 2001, Catts \& Haskell 1990). 
Urban entomology, as used in forensic science, deals with arthropod pests occurring in the human dominated environment involving problems associated with houses and other structures, such as termites. Civil lawsuits can arise because of damage caused by these insects and problems pertaining to their control (Byrd \& Castner 2001, Catts \& Haskell 1990).

Forensic aspects of stored products entomology involve cases of arthropods and/or their body parts in stored and marketed food products or occurring in food sold in restaurants (Byrd \& Castner 2001, Catts \& Haskell 1990). At times entomologists are also called upon when individuals bring about fraudulent acts by placing arthropod parts in products sold to them (Byrd \& Castner 2001).

Medicolegal forensic entomology deals with negligence of people resulting in such things as myasis in children, rest home patients, and corpses in morgues. A subdiscipline of medicolegal entomology is medicocriminal entomology, which involves the calling upon of entomologists to aid with arthropod evidence in criminal investigations (Byrd \& Castner 2001, Catts \& Haskell 1990, Tenorio et al. 2003). This latter aspect of forensic science emphasizes utilizing arthropod evidence in solving crimes most often of a violent nature using two main approaches. One approach takes in account general succession of arthropod communities to aid in estimation of post mortem interval, and the second factors in environmental influences in the development of arthropods (Byrd \& Castner 2001, Catts \& Haskell 1990).

The time elapsed since death before a corpse is discovered, referred to as post mortem interval or PMI, is crucial to investigations. With this information, investigators 
can more accurately separate the innocent from the guilty by eliminating individuals as suspects based on the last person(s) seen with the victim and alibis rendered. Post mortem interval relies on an entomologist's ability to correlate the species or stage of development of arthropods to an elapsed period between a person's death and the discovery of his/her body (Byrd \& Castner 2001, Catts \& Haskell 1990). With entomologists having to correlate stage of development of arthropods with time elapsed before discovery of the body, environmental factors must be taken into account due to their effects on arthropod development and the rates thereof.

Temperature has a profound effect on insect metabolic and developmental rate, with developmental rates increasing with temperature until a point is reached where the temperature becomes detrimental to the developing insect (Byrd \& Castner 2001, Kasson 1999, Davies \& Rattcliffe 1994). If temperature is relatively cool, some insects may diapause in response to seasonal cues increasing time spent in a given stage of the life cycle (Byrd \& Castner 2001).

Insect diversity varies with seasonality, temperature, and geographic location (Erzinclioglu 1983). These factors effect species diversity, but also effect arthropod lifecycles, causing a difference in developmental time, physical size, and body mass (Beck 1983, Davies \& Rattcliffe 1994, Erzinclioglu 1983). For example, dipteran larvae have an optimum range of temperature conducive to their development. As temperature increases, developmental rates for dipteran larvae increase. As developmental rates increase, metabolic heat generated by the larval mass also increases, thus increasing temperature within the carrion. Environmental temperatures, combined with metabolic 
heat produced, can raise larval-mass core temperatures within the carrion above optimum range and thereby could serve as a hindrance, or at times, even be detrimental to larval activity (Kasson 1999).

Insects represent one of the most important sources of forensic evidence. Blow flies (Diptera: Calliphoridae) are usually the first insects to colonize corpses, frequently within minutes after death (Catts \& Goff 1992; Greenberg 1973, 1991). Temperature, whether at night or during the day, plays an important role in the deposition and hatching of eggs and the development of larvae (Beck 1983, Byrd \& Castner 2001, Catts \& Goff 1992, Catts \& Haskell 1990). If a corpse is found, the early stages of diptera present may be used in determining the post mortem interval (PMI) by reverse estimation of the time it would take for eggs to have been deposited and larvae to have developed to the stage they were collected in, using environmental factors such as temperature.

Diverse numbers of blow fly species are known to occur in a given region (e.g., Tenorio et al. 2002), with certain blow fly species active in a variety of temperature ranges. With different species of blow fly active at different temperature ranges, there may be an overlap in temperature levels considered "optimum" for a given species. For example, temperature highs in some wintertime parts of the year are equivalent to lows in the summertime part of the year. If a species of Calliphoridae was active at both times, winter broods would have a much slower development rate than the summer broods and differences in physical size and body mass for the species might occur. These differences could confound an analysis of data obtained for flies collected at distinct times of the year. 
Temperature influences on behavior and growth of blow fly species have been the focal point of numerous studies. Temperatures are usually at their highest diurnally; therefore, it is widely accepted that diurnal temperatures and sunlight are conditions necessary for blow fly oviposition (Greenberg 1990). At times, a nocturnal temperature range is equivalent to diurnal temperatures and debate has arisen as to whether the introduction of artificial light in addition to "optimum" temperatures can create conditions that stimulate blow fly oviposition during nocturnal periods. Research regarding nocturnal oviposition by blow flies has been conducted during summer for both the southern and northern United States, with differing results (Tessmer et al. 1995, Greenberg 1990, respectively). Research performed in the southern state of Louisiana by Tessmer, Meek, and Wright (1995) presents evidence that blow flies do not oviposit on carrion during nocturnal hours. However, research performed in the northern state of Illinois by Greenberg (1990) presents evidence that at least some blow fly species do oviposit on carrion during nocturnal hours. Warm temperatures allow insect activity, including egg deposition, to be at its highest, irrespective of the time of year or time of day (Burt \& Pedgley 1997). Therefore, if insect activity increases due to warm temperatures and warm temperatures persist all twenty-four hours of any given calendar day, then certain insects may be active day or night provided other environmental needs such as light are satisfied (Burt \& Pedgley 1997). Thus, carrion in a well-lit area on a warm summer night could simulate oviposition for dipteran species present as suggested by Greenberg (1990). 
The hypothesis addressed in this thesis is blow fly species, like the kind that occur in Central Texas, would oviposit on carrion during the nocturnal hours under artificial light in the warmer times of the year. If nocturnal oviposition does occur, this event could change PMI estimates by as much as 12 hours (Greenberg 1990).

The two previously mentioned studies in Louisiana (1995) and Illinois (1990) were performed in two completely different habitats and in only one season of the year. To accurately document dipteran behavior patterns for an area, species must be studied throughout year in order to distinguish which behavior is associated with what specific season or seasons of the year in the same geographical ecosystem. The objective of this study attempts to determine nocturnal temperature and artificial light effects on the oviposition and developmental activities of necrophagous, carrion-associating blow fly species common to Central Texas. 


\section{LITERATURE REVIEW}

Knowledge of blow fly egg-laying behavior stems mostly from diurnal studies and research conducted in specific seasons in limited regions of the United States. Published research rarely notes nocturnal oviposition activity in blow flies (e.g. Greenberg 1990, Tessmer et al. 1995). The natures of these particular nocturnal studies are summarized below.

\section{Evidence Supporting Nocturnal Oviposition by Blow Flies}

Greenberg (1990) suggests that blow flies, Calliphora vicina (RobineauDesvoidy), Phormia regina (Meigen), and particularly Phaenicia sericata (Meigen) occasionally oviposit on carrion during nocturnal hours. Greenberg (1990) took decapitated, skinless, previously frozen rat carcasses and transported them in Ziploc ${ }^{\circledR}$ bags to a residential suburb of south Chicago, IL, during the nocturnal hours of June, July and August of 1988. In July and August of 1989, the experiment was repeated at a similar residential site, but using ground beef as bait. During both experiments, the bait was exposed to wild fly populations by placing it on the ground in empty cages under brush and below sodium vapor alley lights. After three nocturnal hours of exposure, the bait was immediately placed back into Ziploc bags with wood shavings and placed in empty fly cages at room temperature. They were no stray flies observed within the cages, during the experiment. At the end of both experiments, adult flies had emerged within the bags, thus providing evidence of nocturnal oviposition by blow flies. 


\section{Evidence Against Nocturnal Oviposition by Blow Flies}

Tessmer, Meek and Wright (1995), furnished evidence contradictory to that of Greenberg (1990), concluding that blow fly oviposition does not occur at night. This study was performed south of Baton Rouge, LA, at the Ben Hur Agriculture Research Station and on the Louisiana State University (LSU) Campus. The Louisiana study used 21 adult white leghorn hens that were euthanized with CO2, plucked, dewinged, and immediately placed into plastic bags for refrigeration. The three evaluation periods of the experiment included 1300-2200 h, 2100-0500 h, and 0600-1300 h. A 1-hour time frame was used to allow adult fly populations to disperse before introducing a new unexposed carcass. Four sites were chosen at the Ben Hur facilities, with only one underneath a 250-watt high-pressure sodium light, and three sites were chosen at the LSU campus, with carrion near or directly under a 400-watt mercury vapor light, a 400watt halide light, and a 250-watt high-pressure sodium light. Each carcass was removed from refrigeration 2 hours prior to exposure and placed atop a 30-cm metal stand to deter red imported fire ants, Solenopsis invicta (Buren), infestations. After each evaluation period, each carcass was examined thoroughly for either calliphorid eggs or sarcophagid larvae. Of all carcasses examined from 2100-0500 h evaluation period, none were found to have any calliphorid eggs present. Of the dipteran species collected and reared during the daylight portion of these experiments, 60\% were Cochliomyia macellaria (F.), 40\% were P. sericata, and $0.001 \%$ was Neobellieria (=Sarcophaga) bullata (Parker). 


\section{Problem Summary}

Although Greenberg (1990) and Tessmer, Meek, and Wright (1995) provide evidence to support their research, the two experiments had few similarities. The dipteran species found in common in both studies was $P$. sericata, which require a surface temperature of $+30^{\circ} \mathrm{C}$ in order to receive proper egg releasing stimuli (Cragg 1956 as reported by Greenberg (1990) and Smith (1986)).

Greenberg's (1990) experiment was conducted in Illinois, which is a very different environment than that of Louisiana. Temperatures for the Illinois experiment ranged from $26-30.5^{\circ} \mathrm{C}$ in comparison to the Louisiana temperatures, which ranged at a lower $22-27^{\circ} \mathrm{C}$. In Louisiana, the temperatures for the $2100-0500 \mathrm{~h}$ evaluation period did not reach $+30^{\circ} \mathrm{C}$, required for $P$. sericata to release eggs. In Greenberg's experiment, the $+30{ }^{\circ} \mathrm{C}$ mark was exceeded by $0.5^{\circ} \mathrm{C}$.

Greenberg conducted his research from June to August of 1988 and July and August of 1989, exposing bait 23 times in a lighted alley of a suburban neighborhood made up of homes where garbage pickup was once a week. This situation maintained a resident population of $P$. regina, and $P$. sericata from May through September (Greenberg 1990). The Louisiana research was conducted in rural, predominantly unlit areas in addition to urban, artificially lit settings. The leghorn carcasses where only exposed for two single 24-hour periods spaced two weeks apart. In the Illinois experiments, carcasses had a larger time frame for egg deposition, as where the Louisiana experiment's leghorn carcasses had only two nine-hour windows of opportunity for nocturnal oviposition. 
Test carrion specimens used in each study differed, with the Illinois experiment using skinless, eviscerated, previously frozen rat carcasses and hamburger as opposed to the use of uneviscerated, plucked, wingless poultry carcasses with the head and feet left in tact, which were chilled at $4.4{ }^{\circ} \mathrm{C}$ for 2 days in the Louisiana experiment. The carrion thus differed in both species of animal involved and method of preservation. In Greenberg's experiment, by freezing the carcasses in the pre-experimental stage, microbial organism growth was halted or reduced (Rosset 1982). With the Louisiana study, the way the poultry was processed gave microbial organisms a chance to contaminate and spread throughout the carcass. Poultry that are not properly processed can encompass a variety of both food poisoning and psychrotrophic spoilage bacteria in their intestines as well as on their feet, feathers, and skin due to fecal contamination, which increases under stressful conditions (Mead 1982). It is a common practice to starve poultry before slaughter to minimize fecal contamination of an individual bird or birds due to an increase in defecation frequency associated with stress and aggregation (Mead 1982). This was not apparently done in the Louisiana study. In addition, scalding hot water is used to loosen the feathers when plucking poultry, but if the water does not reach $60+{ }^{\circ} \mathrm{C}$, bacterial growth has a greater survival rate (Mead 1982). The plucking method in the Louisiana study was not documented. With these factors combined, both the chemical as well as microbial environment in the Louisiana study may have been different from that of Greenberg, in that environmental conditions may not have been conducive in the Louisiana study for nocturnal blow fly oviposition. 


\section{MATERIALS AND METHODS}

\section{Study Site Locations}

The study sites for this investigation were located at the rural home of Dr. Jimmy K. Olson, located $4.02 \mathrm{~km}$ southwest of Snook (Burleson County), Texas, off County Road 246. Dr. Olson's house sits on 1.523 acres of open, mowed, prairie-like habitat void of thick brush southeast (in front) of the house and a densely-wooded area northwest (in back) of the house comprised of mostly post oak trees (Quercus stellata) understoried by yaupon (Ilex sp.) (Fig. 1). Dr. Olson's property is bordered to the southwest by open, prairie-like grassland that is only occasionally mowed; to the southeast (across County Road 246) by pastureland occasionally harboring cattle; to the northeast by a savannah-type habitat consisting of scattered post oak and Acacia trees (Acacia sp.) and unmowed grassland; and to the northwest by post oak woodlands from which the understory of yaupon has been removed.

The "prairieland" study site (Fig. 2; Site A on Fig. 1) used in the current investigation was located ca. $38 \mathrm{~m}$ to the south-southeast of Dr. Olson's house along the fence line between his property and that of his neighbor's to the southwest. The "woodland" study site (Fig. 3; Site B on Fig. 1) was located ca. 38 m to the northwest of Dr. Olson's House on a pathway cut into the wooded area in back of the house. 


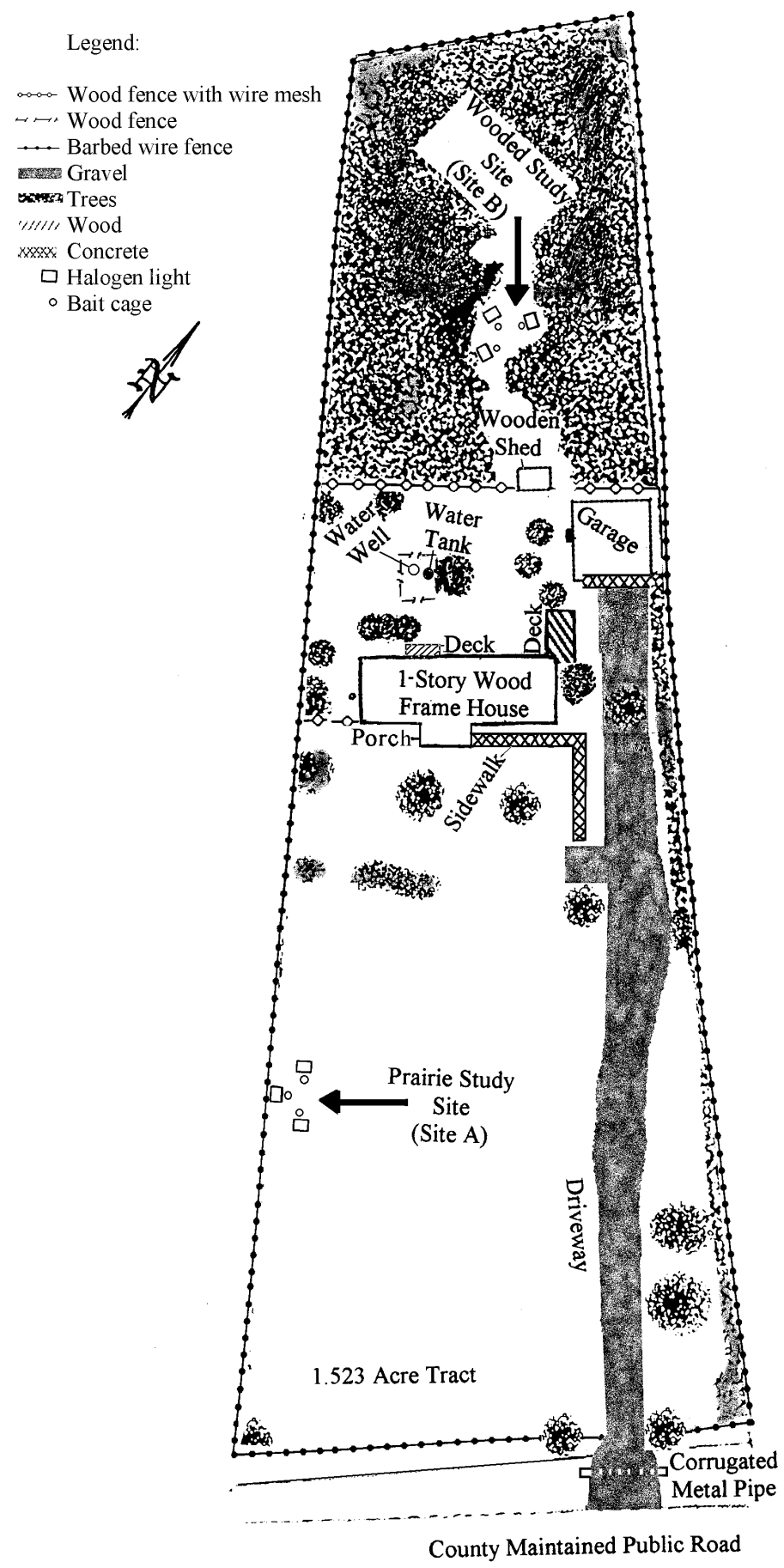

Fig. 1. Diagram of the 2003 rural nocturnal blow fly oviposition research study site near Snook (Burleson County), Texas (scale: $1 \mathrm{~cm}=7.6 \mathrm{~m}$ ). 


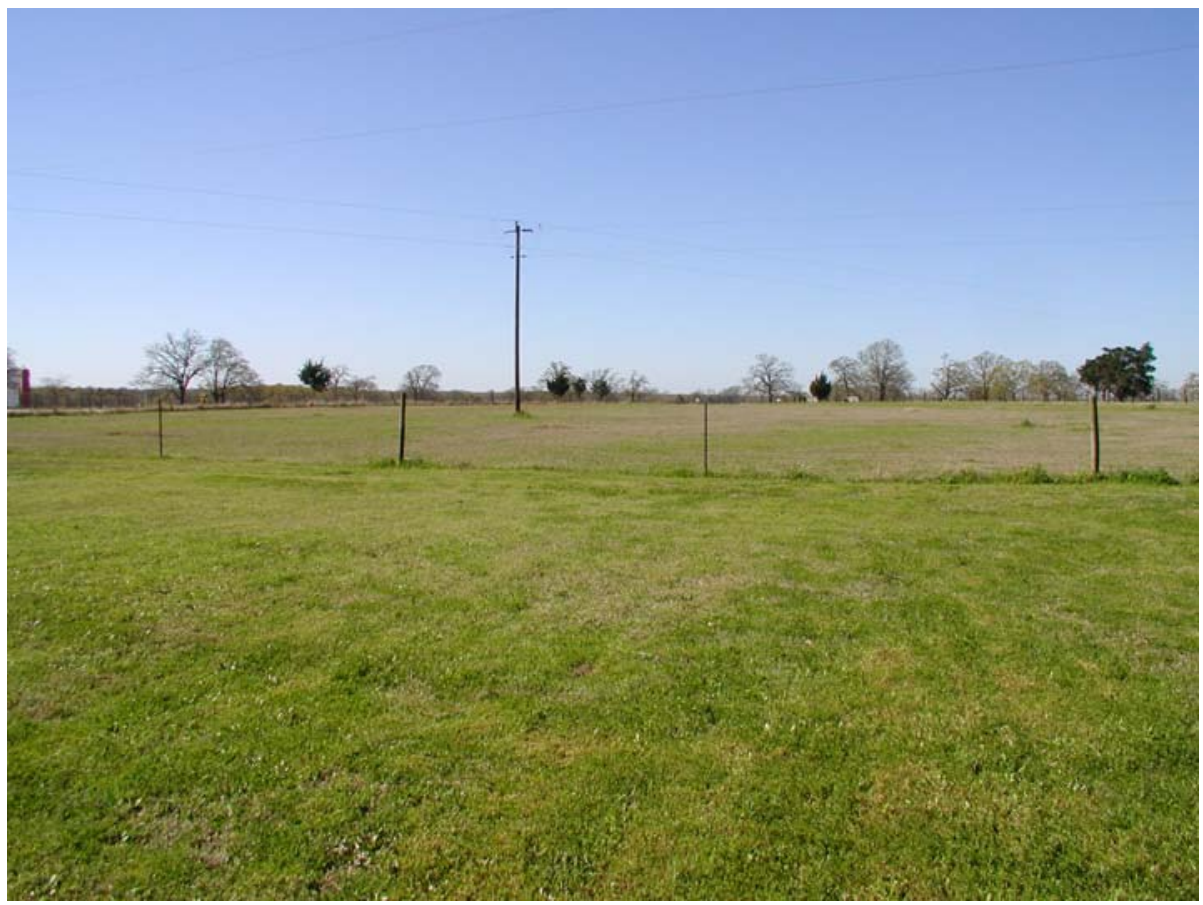

Fig. 2. Prairieland habitat study site used for the nocturnal blow fly oviposition study conducted near Snook (Burleson County), Texas, in 2003.

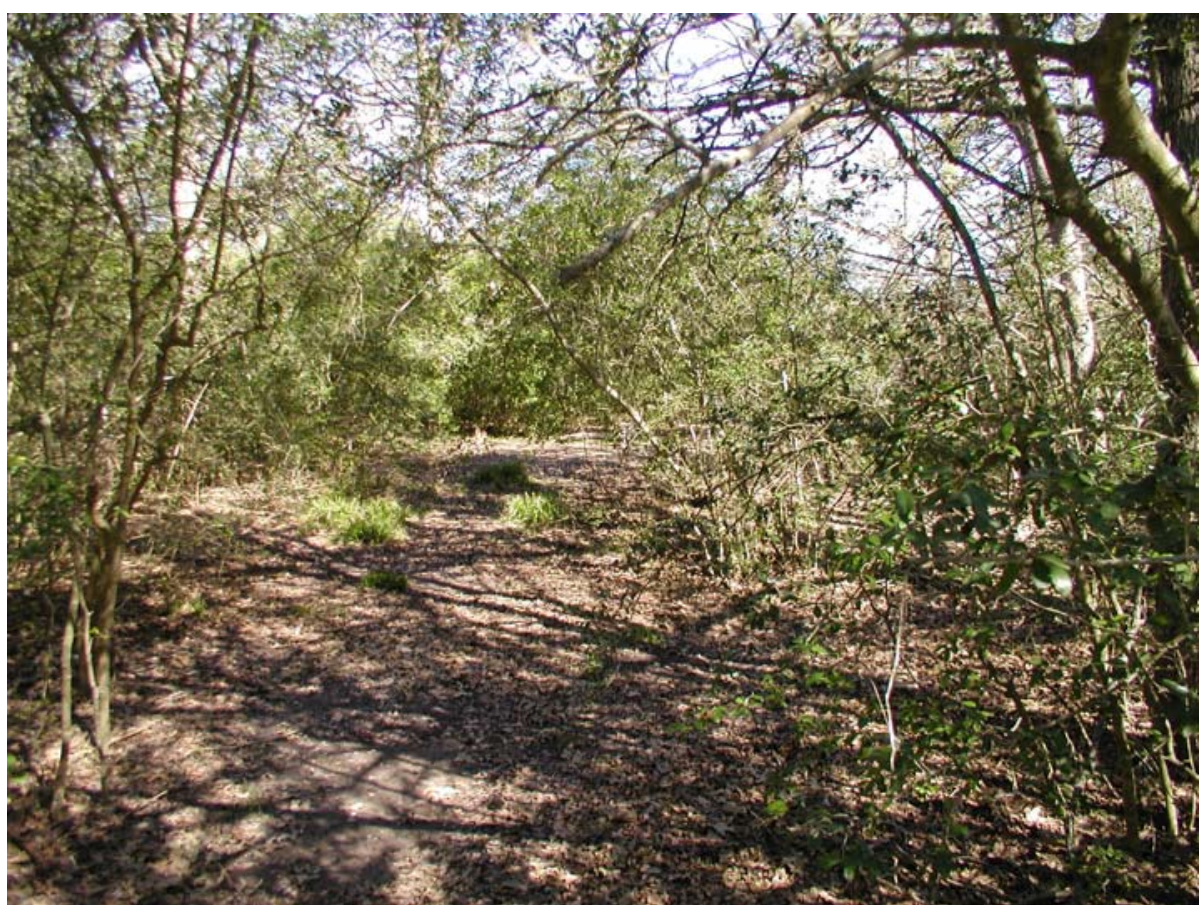

Fig. 3. Woodland habitat study site used for the nocturnal blow fly oviposition study conducted near Snook (Burleson County), Texas, in 2003. 


\section{Nocturnal Blow Fly Oviposition Study}

Investigations into the nocturnal oviposition of blow flies were conducted at the study site just described (Fig. 1) during the defined seasons of spring (June 5-20), summer (June 21-August 14), fall (October 20-30), and winter (December 1-10) in 2003. The methods used in this investigation were patterned after those used by Greenberg (1990) in his nocturnal blow fly oviposition study involving ground beef set out as bait attractants for necrophagous Diptera in an urban environment. In the case of the current study, the environment was rural and the bait used was ground beef ( $80 \%$ beef / 20\% fat) kept frozen at $-4^{\circ} \mathrm{C}$ until it was thawed and used in a given experiment.

As depicted in Figure 1, the two experimental study sites (Site A-Prairieland and Site B-Woodland) were approximately 89 meters apart, and separated by a house and storage shed, which were among the structures located on the premises where the study was conducted. The experimental sites were kept clean of trash and human refuse so as not to create a continuously-human-influenced fly-breeding environment like as was the case in Greenberg's (1990) study. The only fly-breeding habitats noted at the area where the current study was performed were more "natural" in their nature (e.g. animal feces in the pastures surrounding Dr. Olson's property and dead animal carcasses along the road in front of Dr. Olson's property) and characteristic of the type of rural setting in which the study was conducted.

At each experimental study site, three halogen lights (Regent Lighting Corporation model PQ72) were each positioned $1.2 \mathrm{~m}$ above the surface of the ground on a stake (Fig. 4) and $1.6 \mathrm{~m}$ apart from each other (Figs. 5 and 6). These lights were 


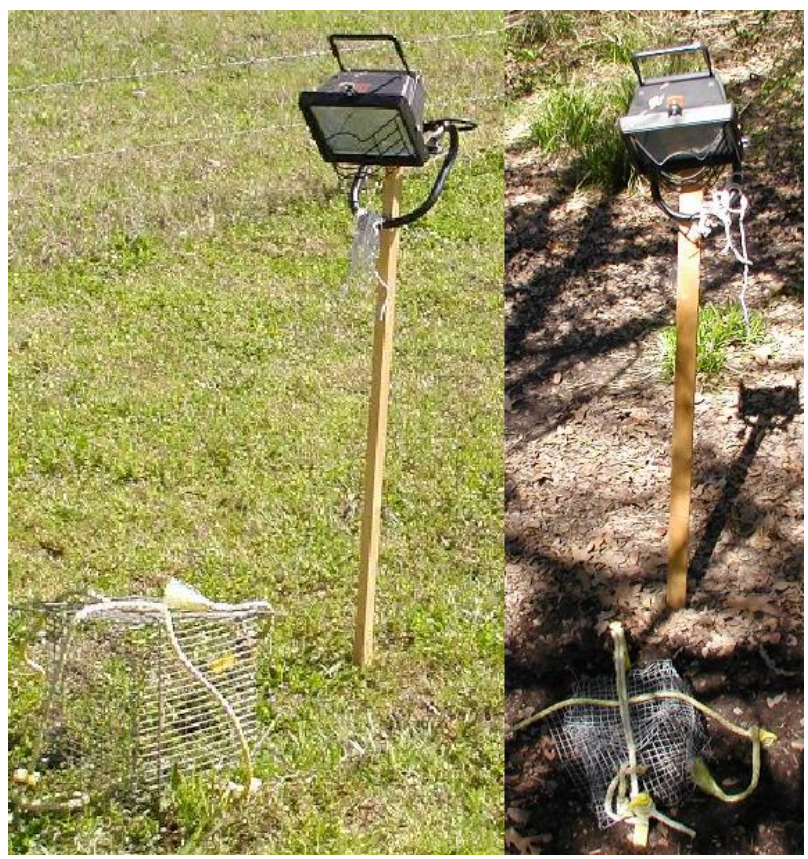

Fig. 4. Individual artificial lighting in prairieland (A) and woodland (B) habitats for 2003 nocturnal oviposition experiments near Snook (Burleson County), Texas.

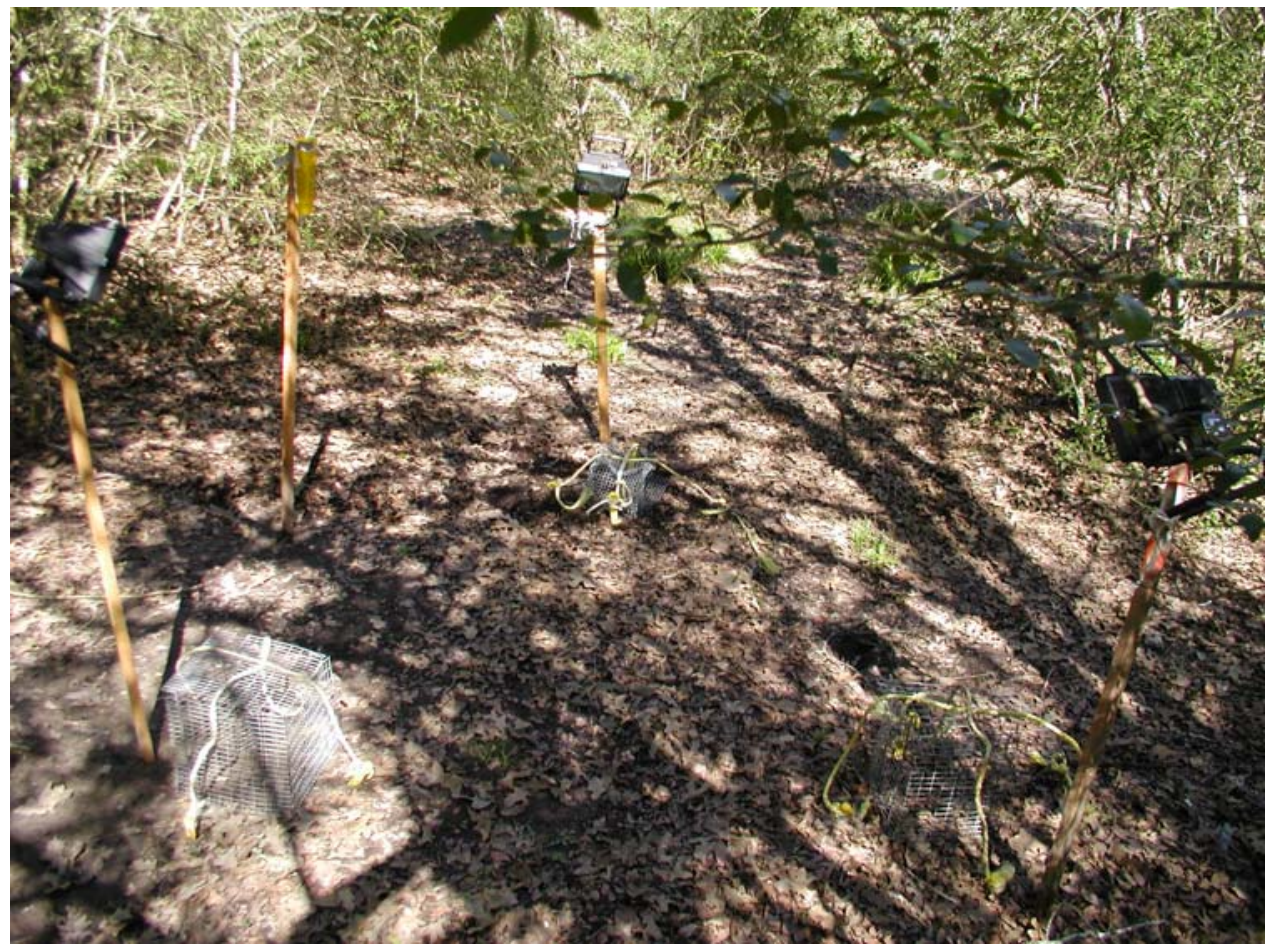

Fig. 5. Artificial lighting system at the 2003 woodland habitat experimental site near Snook (Burleson County), Texas. 


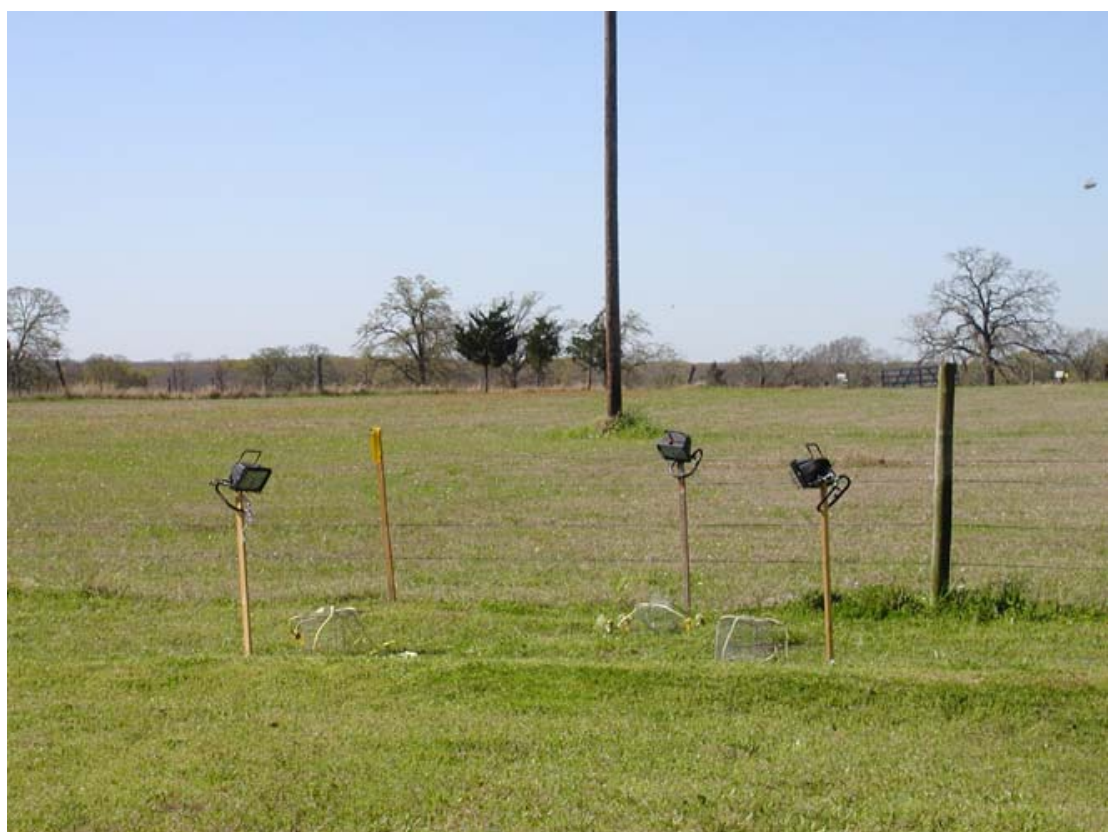

Fig. 6. Artificial lighting system at the 2003 prairieland habitat experimental site near Snook (Burleson County), Texas.

powered by 110 v extension cords leading from external outlets on Dr. Olson's house and created artificial lighting for the oviposition experiments when such was called for. When artificial lighting units were powered on in one experimental habitat, its counterpart experimental habitat had no artificial lighting exposure whatsoever, and was only lighted by natural conditions. Artificial lighting alternated from one given habitat (i.e. prairieland) to the other habitat (i.e. woodland) after a week in the spring trial (June 5-June 20) and summer trial (June 21-August 14) with only one habitat under artificial lighting and the other under natural conditions for seven consecutive days each; and 4 days for the fall trial (October 20-October 30) and winter trial (December 1-10) with 
one habitat under artificial lighting and the other under natural conditions for a consecutive four day period.

In addition to artificial lighting equipment, temperature and rainfall recording equipment was positioned accordingly for environmental readings. Stakes were placed $0.5 \mathrm{~m}$ to the right of the bait stations and digital memory thermometers (Radioshack ${ }^{\circledR}$ digital catalog number 63-1024) were fastened $1.2 \mathrm{~m}$ above the ground to stakes at each experiment site. Additional stakes were placed in the ground to the left of the thermometers and leveled and rain gauges (Springfield $®$ rain gauge) were attached to each stake to measure daily rainfall. Nocturnal and diurnal temperature highs and lows, surrounding ambient temperature, and rainfall were recorded daily and nightly.

In setting up for a given experiment, a $227.2 \mathrm{mg}$ allotment of fresh ground beef, thawed to ambient temperature, was placed at the base of each light stake at both experimental sites. This was done at $1.33 \mathrm{~h}$ after official sunset during nighttime experiments and at 0.5 hours after official sunrise during daytime experiments. Each ground beef allotment was housed in a $21 \mathrm{~cm}$ x $21 \mathrm{~cm}$ x $21 \mathrm{~cm}$ wire mesh boxed fashioned from $1.27 \mathrm{~cm}$-mesh wire hardware cloth and staked to the ground with rope straps to prevent tampering or removal of baits by animals (Figs. 5 and 6). To prevent the ground beef from being infested by fireants (Solenopsis sp.), insecticide (Ortho ${ }^{\circledR}$ Ant Dust and Amdro ${ }^{\circledR}$ Hydramethylnon granules) was disseminated in a 0.3-meter swath around a 12meter perimeter circumference at each of the test sites every night after baits were placed at each site. 
Once an experiment was set up and nocturnal ground beef monitoring had begun, temperature and rainfall were made at each study site and measurements of relative humidity via a Taylor ${ }^{\circledR}$ sling psychrometer, and light intensity via a Quantum Instruments Incorporated Photo Meter $1 \circledR$ pointed at each bait were taken at bait level $1.3 \mathrm{~h}$ and $4.3 \mathrm{~h}$ after official sunset and $1.5 \mathrm{~h}$ before official sunrise during nighttime experiments. After each environmental data reading session, baits were checked thoroughly for blow fly egg deposition, and also periodically checked for fly activity for the first 3 h of nocturnal exposure. Fly eggs, if present, were removed and placed on 3 mg of beef heart and placed in a clean, plastic fly-rearing container (Bioquip ${ }^{\circledR}$ ) with vermiculite and 1 millimeter mesh placed over the openings of the container (Fig. 7). Once eggs were placed on beef heart for rearing, 5 eggs were removed from each given sample and preserved in an $80 \%$ ethyl alcohol in a vial labeled with the appropriate collection data. 


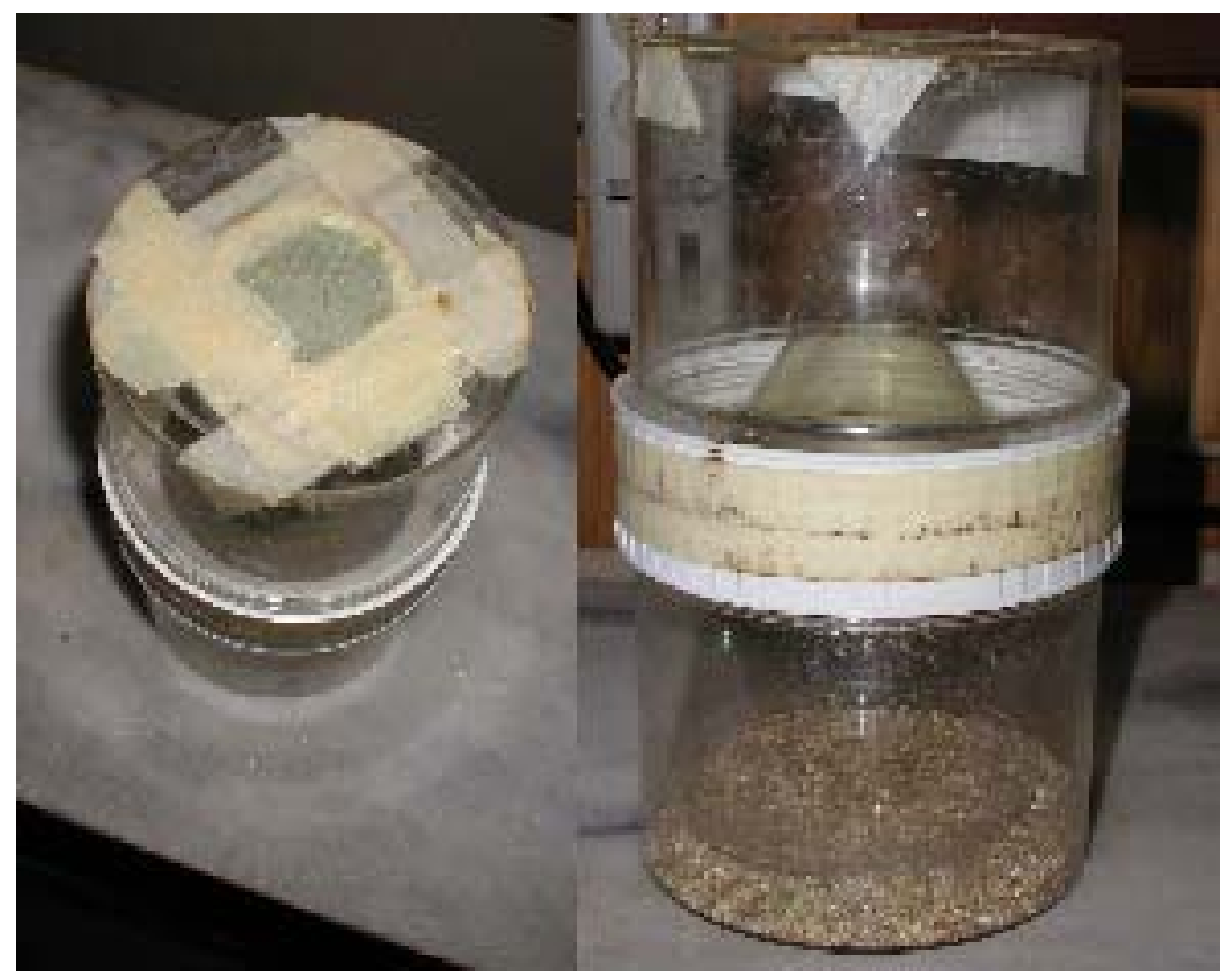

Fig. 7. An example of plastic, modified, Bioquip ${ }^{\circledR}$ rearing containers in which blow fly eggs and larva were reared for 2003 nocturnal oviposition experiments near Snook (Burleson County), Texas.

Once nocturnal monitoring ceased for the night (ca. $1.3 \mathrm{~h}$ before official sunrise), the baits were collected and placed in separate clean, dated, plastic, fly-rearing containers with vermiculite and 1 millimeter mesh over the openings of the containers sealed with masking tape. New ground beef bait allotments were placed at each site 0.5 $\mathrm{h}$ after official sunrise to be used as controls (daytime exposure). These daytime baits were then collected and placed in separate clean, dated, plastic fly-rearing $0.10 \mathrm{~h}$ before official sunset. 
At the end of a given experimental evening, all bait-containing rearing containers were taken back to the TAMU Mosquito Research Laboratory and monitored for fly maggot activity for a week in a constantly-lit room set at a constant temperature of $23.8^{\circ} \mathrm{C}$. Those containers not having any maggots present after one week were thrown out as negative nocturnal oviposition responses.

In the case of positive nocturnal oviposition responses, larvae in the rearing containers were allowed to reach the third instar and then, half of the larvae in each container were heat killed with near boiling water and placed in vials of $80 \%$ alcohol labeled with site locality and collection dates. This was done for larval identification purposes. The remaining larval specimens in each container were allowed to proceed on in their development to the adult stage to confirm larval identifications. Killed larvae and adults from each container were counted, curated and labeled and sorted according to date, experiment trial, habitat, and species.

Upon completion of fieldwork, all specimens were labeled according to location and species and sorted by species, date and site of collection. Data recorded were compared for temperature, light intensity and relative humidity thresholds in accordance to species, date, time, ambient temperature, and Photo Meter $1 \circledR$ light intensity readings. Data recorded from given experimental nights that resulted in a positive nocturnal oviposition response, were tabled in chronological order in accordance to species, date, experiment trial, time, ambient temperature, percent relative humidity, light intensity readings in footcandles, and number of specimens reared from the given ground beef bait. 


\section{Seasonal Blow Fly Oviposition Study}

Control baits monitored diurnally for blow fly oviposition activity at each of the two study sites described in the previous section of this thesis were secondarily utilized as a record of general blow fly activity for the area near Snook (Burleson County), Texas, studied in 2003. In establishing diurnal exposure experiments, halogen lights were disengaged and a $227.2 \mathrm{mg}$ allotment of fresh ground beef ( $80 \%$ beef $20 \%$ fat), thawed to ambient temperature was placed at the base of each nocturnal oviposition experiment light stake $0.5 \mathrm{~h}$ after official sunrise at both experimental sites. Once diurnal exposure activities had ceased 10 minutes before official sunset, baits were placed in separate, clean, fly-rearing containers with vermiculite and $1 \mathrm{~mm}$ mesh over

the openings of the containers sealed with masking tape (Fig. 7). Subsequent to securing the baits in their respective containers, diurnal temperature spectrums and rainfall were recorded from the environmental recording devices previously setup for nocturnal experiments.

Upon leaving the study site, data was recorded and the labeled rearing containers were taken back to the TAMU Mosquito Research Laboratory to be monitored for a week for fly activity in a constantly lit room set at $23.8^{\circ} \mathrm{C}$. If larvae occurred in any of the containers, specimens were allowed to reach the third instar and then, half of the larvae in the given container were heat killed with near boiling water and placed in vial containing $80 \%$ ethyl alcohol and labeled with locality, collection site and date information. These preserved larvae were subsequently used for identification. The remaining specimens in each container were allowed to develop to the adult stage for 
species confirmation. The killed larva and adult specimens were identified, curated, labeled, and sorted according to date, experiment trial, habitat, and blow fly species.

\section{Seasonal Blow Fly Oviposition Study Statistical Analysis}

Once curated and recorded, the array of blow fly species along with environmental data was tabled and time-lined for binary logistic regression analysis. Binary logistic regression statistical analysis program SPSS 11.5 for Windows was used to analyze environmental and species data. In order to perform proper analysis of data, all species active during the study were listed according to date, season, habitat, and an oviposition category was established using binomial distribution with either a 0 or a 1 to identify a species' oviposition activity for each experiment date. Using SPSS 11.5 for Windows, the model y $=$ oviposition + species + season + habitat $+($ species $\mathrm{X}$ season $\mathrm{X}$ habitat $)+($ species $X$ season $)+($ species $X$ habitat $)+($ season $X$ habitat) was created to determined if their were statistical interactions between the independent variables of species, season, and habitat and the dependent variable of oviposition. Through this statistical analysis, binary logistic regression determined whether or not one factor or a combination of factors had an effect on any particular species being present at the study site.

Again using SPSS 11.5 for Windows statistical program, the model $y=$ oviposition + maximum nocturnal temperature + minimum nocturnal temperature + maximum diurnal temperature + minimum diurnal temperature + (maximum nocturnal temperature + minimum nocturnal temperature $\mathrm{X}$ maximum diurnal temperature + minimum diurnal temperature) was formed for a binary regression analysis. 
Independent variables of diurnal and nocturnal maximum and minimum temperatures for each experiment date and a binomial distribution dependent variable of either 0 or 1 to identify species oviposition activity were inserted into the model to analyze whether or not there was an association between nocturnal temperature and diurnal oviposition. 


\section{RESULTS}

\section{Nocturnal Blow Fly Oviposition Activity}

Results of the blow fly nocturnal oviposition experiments conducted in each experiment trial of 2003 in both "prairieland “ and "woodland" research study sites near Snook (Burleson County), Texas, are summarized in Table 1. Nocturnal ovipositing by female blow flies occurred solely under artificial lighting and then, only when there was an onset of low-atmospheric pressure moving into the research area in the June 5-20 and June 21-August 14 experiments (Table 2).

Table 1. Seasonal and environmental data for blow fly species that oviposited nocturnally under artificial lighting conditions during the 2003 nocturnal oviposition study near Snook (Burleson County), Texas.

\begin{tabular}{|c|c|c|c|c|c|c|c|c|c|}
\hline Species & Date & Season & Habitat & $\begin{array}{c}\text { Official } \\
\text { sunset time } \\
\text { Daylight savings } \\
\text { time } \\
\end{array}$ & $\begin{array}{c}\text { Oviposition } \\
\text { time }\end{array}$ & $\begin{array}{l}\text { Ambient } \\
\text { temp } \\
\left({ }^{\circ} \mathrm{C}\right)\end{array}$ & RH, \% & $\begin{array}{c}\text { Artificial } \\
\text { light levels } \\
\text { (FC) }\end{array}$ & $\begin{array}{c}\text { No. specimens } \\
\text { reared }\end{array}$ \\
\hline Phaenicia eximia & June 8 & Spring & Prairie & 18:03 & $21: 10$ & 27.7 & $81 \%$ & 1900 & 26 \\
\hline Phaenicia eximia & June 10 & Spring & Prairie & 18:03 & $21: 30$ & 26 & $84 \%$ & 1500 & 8 \\
\hline Phaenicia eximia & June 10 & Spring & Prairie & 18:03 & $21: 33$ & 26 & $84 \%$ & 1600 & 35 \\
\hline Cochliomyia macellaria & June 10 & Spring & Prairie & $18: 03$ & $21: 30$ & 26 & $84 \%$ & 1600 & 33 \\
\hline Phaenicia eximia & June 19 & Spring & Wooded & 18:05 & $21: 20$ & 28.5 & $75 \%$ & 1800 & 23 \\
\hline Phaenicia eximia & June 21 & Summer & Wooded & 18:05 & $21: 10$ & 28.8 & $73 \%$ & 1700 & 27 \\
\hline Phaenicia eximia & Aug. 8 & Summer & Prairie & 18:09 & $21: 20$ & 26.8 & $72 \%$ & 1700 & 29 \\
\hline Phaenicia eximia & Aug. 14 & Summer & Prairie & 18:08 & $21: 35$ & 27.5 & $80 \%$ & 1500 & 30 \\
\hline
\end{tabular}

At no time did nocturnal oviposition by blow flies occur in either experimental site under "natural” lighting conditions, i.e. when artificial light was absent. Furthermore, no nocturnal egg-laying activity by blow flies was observed during 
October and December trials of the study period in either experimental site irrespective of lighting conditions. As noted in the material and methods section, blow fly species presence in the research area was determined by the presence of eggs laid on beef bait used as daytime controls in both the woodland and prairieland experimental sites during diurnal hours of the four sets of seasonal experiments.

Table 2. Climate data during the 2003 June 5-20 trial for the blow fly nocturnal oviposition research site near Snook (Burleson County), Texas, when nocturnal oviposition occurred under artificial lighting.

\begin{tabular}{|c|c|c|c|c|c|c|c|c|c|c|c|c|}
\hline \multirow[b]{2}{*}{ Date } & \multirow[b]{2}{*}{$\begin{array}{c}\text { Time } \\
\text { Daylight savings } \\
\text { time } \\
\end{array}$} & \multirow[b]{2}{*}{ Habitat } & \multirow{2}{*}{$\begin{array}{l}\text { Moon } \\
\text { phase }\end{array}$} & \multirow[b]{2}{*}{$\mathrm{RH}, \%$} & \multirow[b]{2}{*}{ Rainfall } & \multicolumn{3}{|c|}{ Nocturnal temperatures, ${ }^{\circ} \mathrm{C}$} & \multirow[b]{2}{*}{$\begin{array}{l}\text { Wind } \\
\text { (mph) }\end{array}$} & \multicolumn{3}{|c|}{$\begin{array}{l}\text { Artificial lighting levels } \\
\text { in given habitat, FC }\end{array}$} \\
\hline & & & & & & Ambient & Maximum & Minimum & & Bait 1 & Bait 2 & Bait 3 \\
\hline \multirow[t]{3}{*}{ June 8} & $20: 47$ & Prairie & 1st Qrtr & $82 \%$ & & 28 & 28 & 25.6 & 7 & 1900 & 1600 & 1500 \\
\hline & 21:10 & Prairie & 1st Qrtr & $81 \%$ & & 27.7 & & & 4 & 1900 & 1600 & 1500 \\
\hline & 23:43 & Prairie & 1st Qrtr & $79 \%$ & Trace & 26.3 & & & 6 & 1900 & 1600 & 1500 \\
\hline \multirow[t]{2}{*}{ June 9} & $2: 45$ & Prairie & 1st Qrtr & $85 \%$ & Trace & 25.6 & & & 2 & 1900 & 1600 & 1500 \\
\hline & 4:03 & Prairie & 1st Qrtr & $89 \%$ & & 25.6 & & & 1 & 1900 & 1600 & 1500 \\
\hline \multirow[t]{3}{*}{ June 10} & $20: 48$ & Prairie & 1st Qrtr & $83 \%$ & & 25.8 & 26 & 20.6 & 1 & 1900 & 1600 & 1500 \\
\hline & $21: 30$ & Prairie & 1st Qrtr & $84 \%$ & 0.0508 & 26 & & & 12 & 1900 & 1600 & 1500 \\
\hline & $23: 42$ & Prairie & 1st Qrtr & $86 \%$ & & 25 & & & 9 & 1900 & 1600 & 1500 \\
\hline \multirow[t]{2}{*}{ June 11} & $2: 55$ & Prairie & 1st Qrtr & $90 \%$ & 0.1016 & 21.1 & & & 4 & 1900 & 1600 & 1500 \\
\hline & 4:00 & Prairie & 1st Qrtr & $92 \%$ & 0.1016 & 20.6 & & & 0 & 1900 & 1600 & 1500 \\
\hline \multirow[t]{3}{*}{ June 19} & 20:42 & Wooded & Full & $71 \%$ & & 29 & 29 & 22.5 & 0 & 1800 & 1600 & 1500 \\
\hline & 21:20 & Wooded & Full & $75 \%$ & Lightning & 28.5 & & & 0 & 1800 & 1600 & 1500 \\
\hline & $23: 41$ & Wooded & Full & $80 \%$ & Storm & 28.1 & & & 0 & 1800 & 1600 & 1500 \\
\hline June 20 & 4:07 & Wooded & Full & $89 \%$ & & 22.5 & & & 0 & 1800 & 1600 & 1500 \\
\hline
\end{tabular}


During the 2003 June 5-20 experiments, Phaenicia eximia (Wiedemann) females oviposited on bait under artificial lighting on the nights of June 8 in the prairieland habitat and June 19 in the woodland habitat (Table 1). On the night of June 10, 2003, a P. eximia female began ovipositing on a beef bait under artificial light in the woodland habitat, but was disturbed and finished ovipositing on another bait at the same site upon which a female of another blow fly species, C. macellaria, had already oviposited. In all three instances of oviposition by blow flies in June 2003, a low-pressure system had moved into the research area, causing rain on 8 and 10 June 2003 in the early hours before sunrise. In the case of June 19, a lightning storm was in the area with no occurrence of rain (Table 2).

In the 2003 June 21 - August 14 experiments, the temperatures were at their highest during the day and nocturnal oviposition only occurred in the case of one species of blow fly, P. eximia. On June 21, 2003, a P. eximia female oviposited on bait under artificial light in the woodland habitat, and although diurnal egg-laying instances were low for the prairieland, nocturnal oviposition did occur at this site on August 8 and 14 of 2003 under artificial light as well (Table 1). Again, as with egg deposition instances in the spring, a low-pressure system was moving into the area during the summer period when nocturnal blow fly egg-laying occurred. Rain did fall in the morning hours of June 22, but for August, there were only thunderstorm clouds in the area with no rainfall recorded (Table 3).

During the 2003 October and December experiments, temperatures were low and cool-weather blow fly species began to oviposit on the daytime control baits. Nocturnal 
Table 3. Climate data during the 2003 June 21-August 14 trial for the nocturnal blow fly oviposition research site near Snook (Burleson County), Texas, when nocturnal oviposition occurred under artificial lighting.

\begin{tabular}{|c|c|c|c|c|c|c|c|c|c|c|c|c|}
\hline \multirow[b]{2}{*}{ Date } & \multirow[b]{2}{*}{$\begin{array}{c}\text { Time } \\
\text { Daylight savings } \\
\text { time } \\
\end{array}$} & \multirow[b]{2}{*}{ Habitat } & \multirow{2}{*}{$\begin{array}{l}\text { Moon } \\
\text { phase }\end{array}$} & \multirow[b]{2}{*}{$\mathrm{RH}, \%$} & \multirow[b]{2}{*}{ Rainfall } & \multicolumn{3}{|c|}{ Nocturnal temperatures, ${ }^{\circ} \mathrm{C}$} & \multirow[b]{2}{*}{ Wind } & \multicolumn{3}{|c|}{$\begin{array}{l}\text { Artificial light levels } \\
\text { in given habitat, FC }\end{array}$} \\
\hline & & & & & & Ambient & Maximum & Minimum & & Bait 1 & Bait 2 & Bait 3 \\
\hline \multirow[t]{3}{*}{ June 21} & $20: 35$ & Wooded & Last Qrtr & $67 \%$ & 0 & 29.9 & 29.9 & 23.4 & 7 & 1700 & 1500 & 1800 \\
\hline & $21: 10$ & Wooded & Last Qrtr & $73 \%$ & 0 & 28.8 & & & 5 & 1700 & 1500 & 1800 \\
\hline & 23:45 & Wooded & Last Qrtr & $98 \%$ & 0 & 24 & & & 4 & 1700 & 1500 & 1800 \\
\hline June 22 & $4: 19$ & Wooded & Last Qrtr & $96 \%$ & 0.3048 & 23.5 & & & 2 & 1700 & 1500 & 1800 \\
\hline \multirow[t]{3}{*}{ Aug. 8} & 20:15 & Prairie & 1st Qrtr & $69 \%$ & 0 & 26.8 & 26.8 & 24.2 & 2 & 1700 & 1500 & 1800 \\
\hline & 21:20 & Prairie & 1st Qrtr & $72 \%$ & 0 & 26.8 & & & 2 & 1700 & 1500 & 1800 \\
\hline & $23: 42$ & Prairie & 1st Qrtr & $75 \%$ & 0 & 26 & & & 0 & 1700 & 1500 & 1800 \\
\hline Aug. 9 & $4: 42$ & Prairie & 1st Qrtr & $89 \%$ & 0 & 24.2 & & & 2 & 1700 & 1500 & 1800 \\
\hline \multirow[t]{3}{*}{ Aug. 14} & $20: 10$ & Prairie & Full Moon & $78 \%$ & 0 & 28.2 & 28.2 & 21.7 & 0 & 1700 & 1500 & 1800 \\
\hline & 21:35 & Prairie & Full Moon & $80 \%$ & 0 & 27.5 & & & 0 & 1700 & 1500 & 1800 \\
\hline & $23: 40$ & Prairie & Full Moon & $82 \%$ & 0 & 26.5 & & & 2 & 1700 & 1500 & 1800 \\
\hline Aug. 15 & $4: 48$ & Prairie & Full Moon & $90 \%$ & 0 & 21.7 & & & 0 & 1700 & 1500 & 1800 \\
\hline
\end{tabular}

arthropod activity of any kind was at a minimum and no nocturnal egg-laying on the part

of blow flies occurred during the October and December trials of the 2003 study period.

\section{Seasonal Blow Fly Oviposition Activity}

The 2003 blow fly oviposition during diurnal hours on daytime control baits at the research area near Snook (Burleson County), Texas, is summarized in Tables 4-7. Diurnal climate conditions occurring during the research period are summarized in Tables 8-11. 
For the 2003 June 5-20 experiments, $P$. eximia was the sole blow fly species actively ovipositing on bait in the research study sites, showing no preference in either experiment site nor habitat (Table 4). However, once ambient temperatures increased in the summer season, when the highest temperatures were recorded for the entire study period (Table 8), egg-laying activity differed, with the blow fly species, P. eximia and Phaenicia coeruleiviridis (Macquart) both ovipositing on baits more frequently in the cooler woodland study site, as opposed to the warmer prairieland study site. Overall, very little oviposition activity was recorded for $P$. eximia during the 2003 June 20August 14 experiments for the prairieland site (Tables 5 \& 9).

Table 4. Diurnal blow fly egg-laying activity at the Snook (Burleson County), Texas, experimental sites during the 2003 June 5-20 experiments.

\begin{tabular}{|c|c|c|c|c|c|c|c|c|c|c|c|c|c|c|c|}
\hline Site / species & $\begin{array}{c}\text { June } \\
5 \\
\end{array}$ & $\begin{array}{c}\text { June } \\
6 \\
\end{array}$ & $\begin{array}{c}\text { June } \\
7 \\
\end{array}$ & $\begin{array}{c}\text { June } \\
8 \\
\end{array}$ & $\begin{array}{c}\text { June } \\
10 \\
\end{array}$ & $\begin{array}{c}\text { June } \\
11 \\
\end{array}$ & $\begin{array}{c}\text { June } \\
12 \\
\end{array}$ & $\begin{array}{c}\text { June } \\
13 \\
\end{array}$ & $\begin{array}{c}\text { June } \\
14 \\
\end{array}$ & $\begin{array}{c}\text { June } \\
15 \\
\end{array}$ & $\begin{array}{c}\text { June } \\
16 \\
\end{array}$ & $\begin{array}{c}\text { June } \\
17 \\
\end{array}$ & $\begin{array}{c}\text { June } \\
18 \\
\end{array}$ & $\begin{array}{c}\text { June } \\
19 \\
\end{array}$ & $\begin{array}{c}\text { June } \\
20 \\
\end{array}$ \\
\hline Spring prairie baits & & & & & & & & & & & & & & & \\
\hline P. eximia & & & & & & & & & & & & & & & \\
\hline Spring wooded baits & & & & & & & & & & & & & & & \\
\hline P. eximia & & & & & & & & & & & & & & & \\
\hline
\end{tabular}

Table 5. Diurnal blow fly egg-laying activity at the Snook (Burleson County), Texas, experimental sites during the 2003 June 21-August 14 experiments.

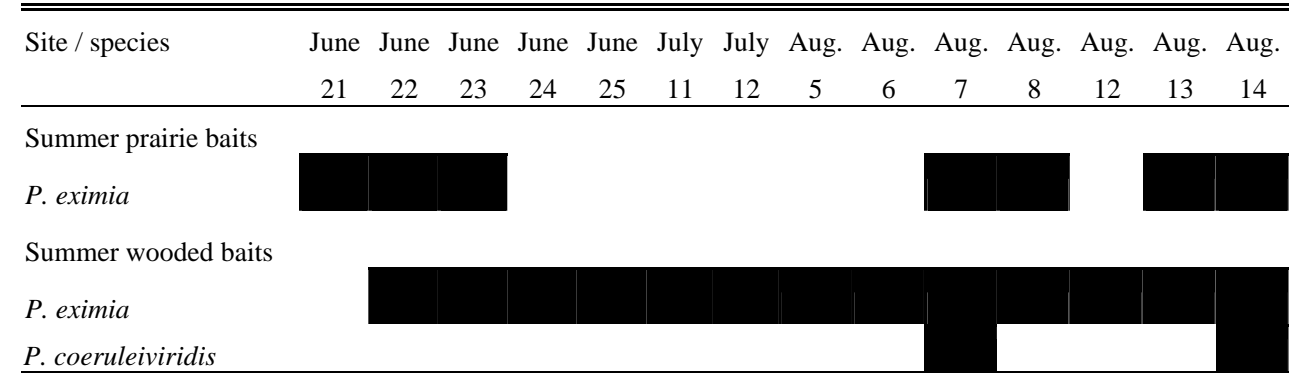


Table 6. Diurnal blow fly egg-laying activity at the Snook (Burleson County), Texas, experimental sites during the 2003 October 20-30 experiments.

\begin{tabular}{|c|c|c|c|c|c|c|c|c|}
\hline Site / species & $\begin{array}{c}\text { Oct. } \\
20 \\
\end{array}$ & $\begin{array}{c}\text { Oct. } \\
21 \\
\end{array}$ & $\begin{array}{c}\text { Oct. } \\
22 \\
\end{array}$ & $\begin{array}{c}\text { Oct. } \\
23 \\
\end{array}$ & $\begin{array}{c}\text { Oct. } \\
27 \\
\end{array}$ & $\begin{array}{c}\text { Oct. } \\
28 \\
\end{array}$ & $\begin{array}{c}\text { Oct. } \\
29 \\
\end{array}$ & $\begin{array}{c}\text { Oct. } \\
30\end{array}$ \\
\hline \multicolumn{9}{|l|}{ Fall prairie baits } \\
\hline \multicolumn{9}{|l|}{ P. eximia } \\
\hline \multicolumn{9}{|l|}{ C. macellaria } \\
\hline \multicolumn{9}{|l|}{ P. regina } \\
\hline \multicolumn{9}{|l|}{ Fall wooded baits } \\
\hline \multicolumn{9}{|l|}{ P. eximia } \\
\hline \multicolumn{9}{|l|}{ Phaenicia cuprina } \\
\hline \multicolumn{9}{|l|}{ C. macellaria } \\
\hline P. regina & & & & & & & & \\
\hline
\end{tabular}

Table 7. Diurnal blow fly egg-laying activity at the Snook (Burleson County), Texas, experimental sites during the 2003 December 1-10 experiments.

\begin{tabular}{|c|c|c|c|c|c|c|c|c|}
\hline Site / species & $\begin{array}{c}\text { Dec. } \\
1 \\
\end{array}$ & $\begin{array}{c}\text { Dec. } \\
2 \\
\end{array}$ & $\begin{array}{c}\text { Dec. } \\
3 \\
\end{array}$ & $\begin{array}{c}\text { Dec. } \\
4 \\
\end{array}$ & $\begin{array}{c}\text { Dec. } \\
5 \\
\end{array}$ & $\begin{array}{c}\text { Dec. } \\
8 \\
\end{array}$ & $\begin{array}{c}\text { Dec. } \\
9\end{array}$ & $\begin{array}{c}\text { Dec. } \\
10\end{array}$ \\
\hline Winter prairie baits & & & & & & & & \\
\hline Cynomyopsis cadaverina & & & & & & & & \\
\hline Winter wooded baits & & & & & & & & \\
\hline $\begin{array}{l}\text { C. cadaverina } \\
\text { P. eximia }\end{array}$ & & & & & & & & \\
\hline
\end{tabular}


Table 8. Diurnal rainfall and diurnal temperature fluctuations for the blow fly oviposition research study site area near Snook (Burleson County), Texas, during the 2003 June 5-20 experiments.

\begin{tabular}{|c|c|c|c|c|c|c|c|c|c|c|c|c|c|c|c|}
\hline Site & $\begin{array}{c}\text { June } \\
5 \\
\end{array}$ & $\begin{array}{c}\text { June } \\
6 \\
\end{array}$ & $\begin{array}{c}\text { June } \\
7 \\
\end{array}$ & $\begin{array}{c}\text { June } \\
8 \\
\end{array}$ & $\begin{array}{c}\text { June } \\
10 \\
\end{array}$ & $\begin{array}{c}\text { June } \\
11 \\
\end{array}$ & $\begin{array}{c}\text { June } \\
12 \\
\end{array}$ & $\begin{array}{c}\text { June } \\
13 \\
\end{array}$ & $\begin{array}{c}\text { June } \\
14 \\
\end{array}$ & $\begin{array}{c}\text { June } \\
15 \\
\end{array}$ & $\begin{array}{c}\text { June } \\
16 \\
\end{array}$ & $\begin{array}{c}\text { June } \\
17 \\
\end{array}$ & $\begin{array}{c}\text { June } \\
18 \\
\end{array}$ & $\begin{array}{c}\text { June } \\
19 \\
\end{array}$ & $\begin{array}{c}\text { June } \\
20 \\
\end{array}$ \\
\hline \multicolumn{16}{|l|}{ Spring prairie diurnal temp } \\
\hline Maximum diurnal temp, ${ }^{\circ} \mathrm{C}$ & 27 & 29 & 32 & 31 & 33 & 35 & 36 & 23 & 32 & 28 & 31 & 22 & 32 & 34 & 34 \\
\hline Minimum diurnal temp, ${ }^{\circ} \mathrm{C}$ & 24 & 22 & 20 & 20 & 20 & 21 & 20 & 21 & 20 & 21 & 22 & 21 & 21 & 22 & 23 \\
\hline Rain, cm & 0 & 0 & 0 & 0 & 0.1 & 0.2 & 0.1 & 2.5 & 0.1 & 0 & 0 & 0 & 0 & 0 & 0 \\
\hline \multicolumn{16}{|l|}{ Spring wooded diurnal temp } \\
\hline Maximum diurnal temp, ${ }^{\circ} \mathrm{C}$ & 26 & 28 & 31 & 30 & 32 & 34 & 35 & 22 & 31 & 28 & 31 & 21 & 32 & 33 & 34 \\
\hline Minimum diurnal temp, ${ }^{\circ} \mathrm{C}$ & 24 & 21 & 20 & 20 & 20 & 20 & 20 & 21 & 20 & 21 & 21 & 21 & 21 & 22 & 23 \\
\hline Rain, cm & 0 & 0 & 0 & 0 & 0.2 & 0.2 & 0.2 & 2.6 & 0.2 & 0 & 0.1 & 0 & 0 & 0 & 0 \\
\hline
\end{tabular}

Table 9. Diurnal rainfall and diurnal temperature fluctuations for the blow fly oviposition research study site area near Snook (Burleson County), Texas, during the 2003 June 21-August 14 experiments.

\begin{tabular}{|c|c|c|c|c|c|c|c|c|c|c|c|c|c|c|}
\hline Site & June & June & June & June & June & July & July & Aug. & Aug. & Aug. & Aug. & Aug. & Aug. & Aug. \\
\hline \multicolumn{15}{|l|}{ Summer prairie diurnal temp } \\
\hline Maximum diurnal temp, ${ }^{\circ} \mathrm{C}$ & 32 & 34 & 34 & 34 & 31 & 39 & 39 & 35 & 36 & 39 & 39 & 30 & 22 & 31 \\
\hline Minimum diurnal temp, ${ }^{\circ} \mathrm{C}$ & 24 & 24 & 24 & 26 & 24 & 28 & 28 & 24 & 24 & 25 & 26 & 20 & 21 & 24 \\
\hline Rain, cm & 0 & 0.4 & 0 & 0 & 0 & 0 & 0 & 0 & 0 & 0.1 & 0 & 0 & 0 & 0 \\
\hline \multicolumn{15}{|l|}{ Summer wooded diurnal temp } \\
\hline Maximum diurnal temp, ${ }^{\circ} \mathrm{C}$ & 32 & 34 & 33 & 33 & 31 & 37 & 38 & 35 & 36 & 38 & 38 & 29 & 31 & 31 \\
\hline Minimum diurnal temp, ${ }^{\circ} \mathrm{C}$ & 23 & 24 & 23 & 25 & 29 & 27 & 27 & 24 & 24 & 25 & 25 & 20 & 22 & 23 \\
\hline Rain, cm & 0 & 0.5 & 0 & 0 & 0 & 0 & 0 & 0 & 0 & 0.1 & 0 & 0 & 0 & 0 \\
\hline
\end{tabular}


Table 10. Diurnal rainfall and diurnal temperature fluctuations for the blow fly oviposition research study site area near Snook (Burleson County), Texas, during the 2003 October 20-30 experiments.

\begin{tabular}{lccccccccc}
\hline \hline \multirow{2}{*}{ Site } & \multirow{2}{*}{ Oct. } & \multirow{2}{*}{ Oct. } & \multirow{2}{*}{ Oct. } & Oct. & \multirow{2}{*}{ Oct. } & \multirow{2}{*}{ Oct. } & \multirow{2}{*}{ Oct. } & \multirow{2}{*}{ Oct. } \\
& 20 & 21 & 22 & 23 & 27 & 28 & 29 & 30 \\
\hline Fall prairie diurnal temp & & & & & & & & \\
Maximum diurnal temp, ${ }^{\circ} \mathrm{C}$ & 28 & 29 & 31 & 32 & 21 & 26 & 26 & 28 \\
Minimum diurnal temp, ${ }^{\circ} \mathrm{C}$ & 12 & 14 & 13 & 16 & 9.5 & 8.9 & 11 & 17 \\
Rain, cm & 0 & 0 & 0 & 0.1 & 0 & 0 & 0 & 0 \\
Fall wooded diurnal temp & & & & & & & & \\
Maximum diurnal temp, ${ }^{\circ} \mathrm{C}$ & 28 & 29 & 31 & 32 & 20 & 25 & 26 & 28 \\
Minimum diurnal temp, ${ }^{\circ} \mathrm{C}$ & 12 & 14 & 13 & 15 & 8.9 & 8.6 & 11 & 17 \\
Rain, cm & 0 & 0 & 0 & 0.1 & 0 & 0 & 0 & 0 \\
\hline
\end{tabular}

Table 11. Diurnal rainfall and diurnal temperature fluctuations for the blow fly oviposition research study site area near Snook (Burleson County), Texas, during the 2003 December 1-10 experiments.

\begin{tabular}{lccccccccc}
\hline \hline Site & Dec. & Dec. & Dec. & Dec. & Dec. & Dec. & Dec. & Dec. \\
& 1 & 2 & 3 & 4 & 5 & 8 & 9 & 10 \\
\hline Winter prairie diurnal temp & & & & & & & & \\
Maximum diurnal temp, ${ }^{\circ} \mathrm{C}$ & 22 & 18 & 20 & 24 & 17 & 23 & 23 & 7.8 \\
Minimum diurnal temp, ${ }^{\circ} \mathrm{C}$ & 11 & 9.8 & 5.8 & 5.8 & -3 & 14 & 3.9 & -1 \\
Rain, cm & 0 & 0 & 0 & 0 & 0 & 0 & 0 & 0 \\
Winter wooded diurnal temp & & & & & & & & \\
Maximum diurnal temp, ${ }^{\circ} \mathrm{C}$ & 21 & 17 & 20 & 23 & 16 & 22 & 22 & 7 \\
Minimum diurnal temp, ${ }^{\circ} \mathrm{C}$ & 12 & 10 & 6.3 & 6.5 & -1.0 & 14 & 4.7 & 2 \\
Rain, cm & 0 & 0 & 0 & 0 & 0 & 0 & 0 & 0 \\
\hline
\end{tabular}

During fall of 2003, four species of blow fly actively oviposited on baits at the research sites (Table 6). Blow fly species ovipositing on baits at the prairieland site during the fall included $P$. eximia, Phormia regina (Meigen) and $C$. macellaria, with $P$. regina beginning oviposition activity on the coldest day of the fall research period 
(Tables 6 and 10). Concomitantly, there was no blow fly egg-laying activity in the woodland habitat for October 20 or October 21 of 2003; but, in the third day of the experiment, three blow fly species [P. eximia,, C. macellaria, and Phaenicia cuprina (Wiedemann)] began to oviposit on baits. When diurnal temperatures were at the lowest point of the October study, as with the prairieland habitat, P. eximia and C. macellaria ceased egg-laying activity and P. regina began to oviposit on woodland baits (Tables 6 \& 10). Also note, scorpionflies (Mecoptera: Panorpidae), known to feed on dead insects, and at times dead animal tissue (Borror et al.1989) were observed feeding on the baits in large numbers at the woodland research site. Once temperatures rose to levels equivalent to those at the beginning of the October trial, $P$. eximia and $C$. macellaria resumed oviposition and $P$. regina along with Panorpidae were no longer detected at either study site (Tables 6 \& 10).

During the 2003 December 1-10 experiments, only one major blow fly species was observed ovipositing on baits, i.e. Cynomyopsis cadaverina (Robineau-Desvoidy), in either habitat, with P. eximia actively ovipositing on baits on December 1 and 2 of 2003 in the woodland experimental site (Table 7). C. cadaverina oviposited daily on baits in the woodland research site, but only oviposited on baits the second, sixth and seventh day of December research at the prairieland study site. On December 5 and 10, there was no blow fly oviposition activity in either habitat of the research site, possibly due to falling temperatures, which extended into the night (Table 11). 


\section{Statistical Analysis of Diurnal Blow Fly Activity}

In estimating what season and habitat is the most conducive to diurnal oviposition by blow fly species as well as determine what effects, if any, nocturnal temperature fluctuations have on blow fly oviposition, data (on blow fly species oviposition occurrence, habitat type, and seasons) along with nocturnal and diurnal maximum and minimum temperatures were analyzed independent of each other with SPSS 11.5 for Windows statistical analysis program using binary regression.

To establish what habitat and season is most conducive to blow fly egg-laying activity, interactions between variable combinations (2 variable combination and 3 variable combinations of insect, season and habitat) were analyzed through SPSS 11.5 for windows statistical analysis program’s binary logistic regression using the model oviposition $=$ insect + season + habitat $+($ insect $\mathrm{X}$ season $)+($ insect $\mathrm{X}$ season $\mathrm{X}$ habitat $)$. Results showed the only significant interaction was the two-way interaction of insect and season, with a high Fisher score of 238.260. The Fisher score is a simple method of scoring linkage data based on maximum likelihood formulae to obtain: 1) a test of significance of the deviations from independent assortment for each source of data as well as for the pooled data, 2) a test of the homogeneity of the group of linkage intensities to be combined, and 3) the average or combined p value (Fisher 1946). Looking at this interaction along with the predictor values of insect, season and habitat, SPSS showed what interactions were conducive to oviposition with a predicted probability cutoff value of 0.5 , which is the level of predicted probability conducive for blow fly oviposition (Table 12). 
Table 12. Binary logistic regression analysis results giving predicted probabilities for seasonal blow fly species oviposition activity at prairieland and woodland habitat study sites near Snook (Burleson County), Texas, during 2003.

\begin{tabular}{lrrrrrrrr}
\hline \hline & \multicolumn{2}{c}{ June 5-20 } & \multicolumn{3}{c}{ June 21-August 14 } & \multicolumn{2}{c}{ October 20-30 } & \multicolumn{2}{c}{ December 1-10 } \\
\cline { 2 - 9 } Species & Prairie & Wooded & \multicolumn{1}{c}{ Prairie } & Wooded & Prairie & Wooded & Prairie & Wooded \\
\hline P. eximia & 0.665 & 0.868 & 0.5976 & 0.8309 & 0.49 & 0.7604 & 0.064 & 0.1856 \\
P. coeruleiviridis & 0 & 0 & 0.0352 & 0.1077 & 0 & 0 & 0 & 0 \\
P. cuprina & 0 & 0 & 0 & 0 & 0.064 & 0.1856 & 0 & 0 \\
C. macellaria & 0 & 0 & 0 & 0 & 0.189 & 0.4358 & 0 & 0 \\
P. regina & 0 & 0 & 0 & 0 & 0.102 & 0.2718 & 0 & 0 \\
C. cadaverina & 0 & 0 & 0 & 0 & 0 & 0 & 0.564 & 0.8108 \\
\hline
\end{tabular}

Conditions in the prairieland habitat during spring proved to be conducive to oviposition by the blow fly species, P. eximia, with a predicted probability of 0.66531 , while as the woodland habitat in the spring trial was more conducive to the species $P$. eximia, with a predicted probability of 0.86803 (Table 12). In the summer trials, both habitats were conducive for oviposition by $P$. eximia, with a predicted probability of 0.59764 for prairieland habitats and 0.83093 for woodland habitats (Table 12).

Likewise, for P. coeruleiviridis, which only oviposited twice during the summer trial and then only in the woodland research study site, had a predicted probability of less than 0.5 for that habitat and zero probability for the prairieland habitat. Thus, neither habitat proved conducive for oviposition by P. coeruleiviridis during the summer of 2003 (Table 12). In the 2003 October 20-30 experiments, only the woodland habitat was conducive to $P$. eximia blow fly species oviposition activity, with a predicted probability of 0.76041 (Table 12). For other blow fly species ovipositing during the fall trial, predicted probabilities for oviposition were all less than 0.5 , indicating neither habitat to 
be conducive for this particular blow fly species' oviposition activity during the fall of 2003 (Table 12). The December 1-10 experiments only had two species of blow flies actively ovipositing (P. eximia and C. cadaverina), only one of which, C. cadaverina had predicted probabilities 0.5 or greater, indicating both habitats were conducive to oviposition by that species (Table 12). Residual plots had no pattern, which signified a good fit for the model (Ott \& Longnecker 2001).

In order to determine what effects, if any, nocturnal temperature fluctuations have on daytime blow fly oviposition activity in the research area; SPSS 11.5 for windows statistical analysis program compared 2 diurnal oviposition models with maximum and minimum temperatures as the altered variables. With the above mentioned statistical analysis program, the 2 diurnal oviposition models compared were diurnal oviposition $=$ insect + maximum temperature nocturnal + minimum temperature nocturnal + (insect X maximum temperature nocturnal X minimum temperature nocturnal) and diurnal oviposition $=$ insect + maximum temperature diurnal + minimum temperature diurnal + (insect X maximum temperature diurnal X minimum temperature diurnal). To reduce the effects that temperature data may have on the models, nocturnal data records for baits not exposed in a consecutive day were excluded in the data set.

After running the binary regression program, the Fisher score had a higher interaction between oviposition and nocturnal temperatures with a score of 227.197 compared to the interaction between oviposition and diurnal temperatures with a score of 211.923. Binary logistic regression results gave a much higher predicted probability for nocturnal temperatures than diurnal temperatures for diurnal oviposition by the blow fly 
species, P. eximia and C. cadaverina. Binary logistic regression results for other blow fly species in the experiment sets were inconclusive for diurnal oviposition based on either diurnal or nocturnal temperatures, with predicted probabilities of less than 0.5 for each given species (Table 13).

Table 13. Predicted probabilities for nocturnal temperature effects on diurnal ovipositing by blow fly species at the 2003 research study site near Snook (Burleson County), Texas.

\begin{tabular}{|c|c|c|c|c|}
\hline \multirow[b]{2}{*}{ Species } & \multirow{2}{*}{ June 5-20 } & \multicolumn{2}{|c|}{ June 21-August 14 October 20-30 } & \multirow{2}{*}{$\begin{array}{l}\text { December } 1-10 \\
\text { C. cadaverina }\end{array}$} \\
\hline & & P. eximia & P. eximia & \\
\hline Maximum nocturnal temp, ${ }^{\circ} \mathrm{C}$ & 28 & 28.5 & 29.9 & 12 \\
\hline Minimum nocturnal temp, ${ }^{\circ} \mathrm{C}$ & 19.4 & 19.4 & 19.8 & 5.8 \\
\hline Oviposition probability & 0.65118 & 0.65118 & 0.7276 & 0.57061 \\
\hline
\end{tabular}

For the June 5-20 trials, nocturnal temperatures between 19.4 - $28^{\circ} \mathrm{C}$ were conducive for the blow fly species, P. eximia ovipositing the following day, with a predicted probability of 0.65118 (Table 13). Days that were preceded with nocturnal temperatures higher than $19.4{ }^{\circ} \mathrm{C}$ had a higher predicted probability for diurnal oviposition; and in all cases for the spring study, predicted probabilities for nocturnal temperatures were higher than that of those of the diurnal temperatures.

In the June 21-August 14 trials, nocturnal temperatures of $19.4-29.5^{\circ} \mathrm{C}$ were conducive for egg-laying activity of P. eximia, with a predicted probability of 0.65118 (Table 13). Fall trials were in the same temperature range in some instances in relation to spring and summer nocturnal temperatures, with fall temperatures conducive to $P$. 
eximia ovipositing being 19.8 - $29.9^{\circ} \mathrm{C}$, with a predicted probability of 0.7276 (Table 13), and some probabilities at 0.85 in the higher end of the temperature range.

December 1-10 trials results had a decrease in P. eximia oviposition activity, being replaced by $C$. cadaverina as the primary ovipositing blow fly species for the research study sites. With this later species being more of a cool weather fly, temperatures dropped creating a temperature range from $5.8-12{ }^{\circ} \mathrm{C}$, conducive for $C$. cadaverina diurnal ovipositing at a predicted probability of 0.5761 (Table 13). Predicted probabilities for temperatures conducive to diurnal oviposition only ranged from 0.57061 to 0.7276 at $12{ }^{\circ} \mathrm{C}$ for the December $1-10$ experiment set. 


\section{DISCUSSION}

\section{Nocturnal Oviposition by Blow Flies}

Results of the study described herein indicate that at least some species of blow flies occurring in Central Texas will deposit eggs during nocturnal hours. However, this appears to happen only when certain habitat conditions are met. In both habitats of the above-mentioned study, blow flies oviposited on baits during nocturnal hours only when a combination of artificial lighting, warm temperatures, and the onset of low-pressure atmospheric conditions were present. At no time did blow flies oviposit during nocturnal hours when one of these conditions was absent from the study site. Although two of the environmental conditions (e.g. artificial lighting and warm temperatures) were present throughout the spring and summer studies, the key factor for blow fly nocturnal oviposition activity was the onset of low-atmospheric pressure. Therefore, it is suspect that there is an unspecified association between the onset of low-atmospheric pressure in warm, artificially lit areas and nocturnal oviposition by blow flies in Central Texas.

One reason for the blow flies' responses to atmospheric pressure changes may lay in particular bristles on these insects' exoskeleton. Bristles found on insects serve in functions such as chemoreceptors, pressure-sensitive receptors, and hygroreceptors (Romoser \& Stoffolano 1998). Pressure-sensitive receptor and hygroreceptor bristles enable insects to detect the compression and moisture of air (Romoser \& Stoffolano 1998), which are conditions associated with low-atmospheric pressure. If insects, blow flies in this case, are able to sense air compression and moisture, there is a possibility then, that they may also sense a change in atmospheric pressure in their environment that 
creates cool moisture. Additional moisture to an environment (e.g. carrion) would serve beneficial to female Calliphoridae, whose larvae require high carcass moisture content for development (Haines \& Rees 1989). Thus, a female blow fly that senses atmospheric pressure conducive to moisture production may be stimulated to oviposit on carrion in a nocturnal setting given the presence of artificial light and warm temperatures.

This occurrence of nocturnal oviposition activity by blow flies under artificial lighting held true during the warmer spring and summer seasons in the current study; but, in the much cooler fall and winter seasons, no nocturnal oviposition by blow flies occurred irrespective of lighting conditions and/or atmospheric conditions. The lack of warm temperatures in these seasons of the year, an environmental factor in nocturnal oviposition by blow flies for this study, created conditions in which blow fly activity ceased after sunset.

The research results described in this thesis, along with the research conducted by Greenberg (1990), gives entomologists evidence that nocturnal oviposition by blow flies does occur. With this distinct possibility, post mortem interval estimates using blow fly development information may have to be adjusted in given circumstances to take in account the possibility of nocturnal ovipositing on the corpse in question by blow flies.

This knowledge warrants further investigation by forensic entomologists into the possibility of blow fly oviposition occurring nocturnally in warm, artificial-lit settings during changes in atmospheric pressure. Although low in number, the occurrence of 
nocturnal oviposition by blow fly species under artificial lighting gives entomologists a new look into the ovipositing behavior by blow fly species, at least as they occur in the Snook (Burleson County) area of Texas.

\section{Seasonal Blow Fly Activity}

As noted in the nocturnal blow fly oviposition study just discussed, the primary blow fly species ovipositing on baits at the research site near Snook, Texas, during the 2003 was $P$. eximia. Although ovipositing primarily during the spring, summer and fall experiments in the current study, $P$. eximia oviposited on occasion during the colder December 1-10 experiments as well, confirming the research done by Mauricio Moura in Parana, Brazil (1997), which indicated that P. eximia does not seem to be restricted to either season or habitat for egg-laying activity.

When present and active in a given area, $P$. eximia is often one of the first blow

fly species to arrive on carrion in the fresh stage. This species has been collected from a large list of carrion, including human corpses, pig carcasses, rat carcasses and processed beef in all seasons of the year and in a wide array of habitats, with its development time ranging between 13 and 20 days (Moura et al. 1997, Kirkpatrick \& Olson 2001). With no apparent seasonal or habitat restrictions, this species is a potentially key species in estimating post mortem intervals at any time of year. Yet, little is known morphologically about this blow fly species' larvae. It is pertinent that this blow fly species be studied more thoroughly as to its morphology as well as its reproductive behavior due to its potential forensic importance because of its nocturnal and year round 
oviposition behavior. Phaenicia eximia stands to be a critical species in determining post mortem interval at least in Central Texas, and warrants investigation.

Another observation made during the course of the research described herein was that blow flies occurring at the Snook, Texas, research site oviposited on baits at a higher frequency, irrespective of species or time of year, in the woodland study site as compared to the prairieland study site during 2003. Though the only statistically-proven interaction was between blow fly species and seasonal temperatures, binary regression statistical analysis results substantiated that the woodland study site was more favorable than the prairieland study site for all blow fly species ovipositing on baits regardless of the time of year in the 2003 experiments, with higher predicted probabilities for the woodland study site (Table 12).

One explanation for higher egg deposition frequency by blow flies in the woodland environment may lie in previous experiments conducted by Mauricio Moura (1997). Moura’s (1997) experiments dealt with rat carcasses and compared decomposition rates in an open environment versus a forested environment. The results of these experiments resulted in a larger number of necrophagous insects, a higher relative humidity, higher temperatures and a slower carrion decomposition rate for the forested environment as compared to the open habitat. With forested/woodland environments supporting slower decomposition rates, higher relative humidities, and higher temperatures than an open/prairieland environment as recorded in the Moura (1997) study, blow flies may have a longer window of opportunity for oviposition development as larvae. With this longer opportunity for development and a blow flies 
instinctive behavior to oviposit on carrion, there may also be another possible instinctive behavior for a blow fly to choose to oviposit on carrion in a forested environment rather carrion in an open, prairielike environment when given a choice. This hypothesis seems reasonable due to an insect's drive for propagation of their species, as seen in mayflies that do not feed as adults and only live for a day to propagate (Borror \& White 1970).

Prior to the research described herein, no previous research has been reported in the literature on nocturnal temperature fluctuations and their effects on diurnal oviposition activity of blow flies. Results of the statistical analysis of ambient temperature data (nocturnal and diurnal) and diurnal ovipositing data for blow flies collected during the current study gives strong evidence that nocturnal temperatures have more of a significant effect on diurnal ovipositing by the blow fly species P. eximia and C. cadaverina than do diurnal temperatures. Nocturnal temperatures ranging from 19.4 to $29.9^{\circ} \mathrm{C}$ had both a higher Fisher score and higher predicted probabilities than did diurnal temperature in regards to P. eximia oviposition. Likewise, cooler, nocturnal temperature ranging in between 5.8 and $12.0^{\circ} \mathrm{C}$ had statistically to have more of an effect on the diurnal oviposition behavior of the cool season species, C. cadaverina than did the diurnal temperatures with a higher Fisher score and higher predicted probabilities occurring for this species when nocturnal temperatures were used. With both blow fly species, P. eximia and C. cadaverina having higher Fisher scores and predicted probabilities for nocturnal temperatures, it is statistically valid to state that nocturnal temperature fluctuations have more of an effect on diurnal oviposition behavior than diurnal temperatures, even though diurnal temperatures may be optimum for fly activity. 
The effects of nocturnal temperature on insect activity as just described are relatively unknown and undocumented. It is thus, pertinent not just in forensic entomology, but entomology in general that the effects of nocturnal temperatures on insect behavior be more fully investigated. In case of Forensic entomology, knowledge of the effects of nocturnal temperatures on blow fly occurrence and oviposition behavior will lead to more accurate estimates of such items as post mortem interval in the future. 


\section{CONCLUSION}

Based on the results of this research, three primary discoveries were made which impact what entomologists know about blow fly behavior. The first major discovery is that the blow fly species, P. eximia and C. macellaria will oviposit during the nocturnal hours of spring and summer seasons under artificial lighting, only when there is an onset of a low-atmospheric pressure system. Secondly, with no previous research on the subject being reported in the literature, nocturnal temperatures appear to have a greater effect on diurnal blow fly egg deposition for the blow fly species, P. eximia and $C$. cadaverina than do diurnal temperatures. Last of all, with no apparent seasonal or habitat restrictions for oviposition, P. eximia can oviposit year round, making it one of the most important blow fly species in determining PMI.

In relation to the first discovery, taking into account previous research on blow fly oviposition behavior (i.e. Greenberg 1990 and Tessmer et al. 1995) along with the results of this research, some blow fly species, in this case P. eximia and C. macellaria may nocturnally oviposit on a corpse in the spring and summer seasons only under artificial lighting and then, only when there in an influx of low-atmospheric pressure. Currently there is no known connection between blow flies and atmospheric pressure systems, but this research shows promise. More research is needed to determine the relevance between the onset of low-atmospheric pressure and blow fly nocturnal egg deposition under artificial lighting. With the debate still unsettled over whether or not blow flies are reproductively active at night under any conditions, more research on all aspects of the nocturnal activities of blow flies is needed. 
Within the nocturnal arena of blow fly behavior, there is yet another primary finding that is a result of this research. Nocturnal temperature fluctuations were statistically proven to have an effect on the oviposition behavior of the blow fly species, P. eximia and C. cadaverina. Prior to the research described herein, no previous study has been reported in the literature on nocturnal temperature fluctuations and their effects on diurnal oviposition activity of blow flies. Few research experiments divulge what takes place in the nocturnal world of insects when people are sleeping. Most information that is known about blow fly oviposition behavior reported in the literature come from diurnal studies when blow flies are observed during the hours humans are most active. With two nocturnally-associated findings reported in this thesis, there is a definite need for more nocturnal blow fly research. Answers to existing questions about blow fly behavior may lie in the nocturnal realm rather than the diurnal one, with the latter realm having received most of the research attention to date.

In regard to $P$. eximia parse, this was the only blow fly species found ovipositing nocturnally as well as diurnally throughout the entire 2003 experimental period irrespective of season or habitat. This particular species of blow fly was the primary one from which most of the ovipositing data was collected during the current study. Like as previously reported by Moura (1997), P. eximia females were found actively ovipositing in each season of the 2003 study regardless of habitat, which leads to the conclusion that this species of blow fly may be one of the most important in determining PMI in Central Texas. Due to the resemblance of this blow fly species' larvae to that of $P$. coeruleiviridis larvae, it is pertinent that entomologists develop a method of identifying 
P. eximia in the larval stage whether the methods to do this are morphologically or genetically based. Determining PMI is one of the foundations of medicocriminal entomology and being unable to identify a blow fly species like P. eximia in the larval stage may inhibit determining PMI in the event that larvae do not live to the adult stage.

The fact that a species like P. eximia is present in a given area year round, information on the effects of seasonal changes in environmental conditions on the occurrence and behavior of such fly species must be gathered and kept current to accurately portray that species as it pertains to forensic investigations. An ever-changing environment gives rise to changes in insect behavior, thus it is important for entomologist to understand how these changes effect insects and their behavior. Also, basing decisions on information that was gathered from an area fifty years ago may not be a wise decision if that environment and its effects on insect species and their behavior have not been looked at since then. In order to present insect evidence accurately in a court of law, environmental information must be kept up-to-date and accurate; for, the reputation of forensic entomology depends on it. 


\section{REFERENCES CITED}

Beck, S. D. 1983. Insect thermoperiodism. Ann. Rev. Entomol. 28 : 91-108.

Borror, D. J., C. A. Triplehorn, and N. F. Johnson. 1989. An introduction to the study of insects, $6^{\text {th }}$ ed. Saunders College Publishing, Fort Worth, TX.

Borror, D. J. and R. E. White. 1970. A field guide to insects. Houghton Mifflin Co., Boston, MA

Burt, P. J. A., and D. E. Pedgley. 1997. Nocturnal insect migration., p. 82-83; In M. Begon and A.H. Fitter, (ed). Advances in ecological research. Academic Press, New York.

Byrd, J. H., and J. L. Castner. 2001. Forensic entomology : The utility of arthropods in legal investigations. CRC Press, New York.

Catts, E. P., and M. L. Goff. 1992. Forensic entomology in criminal investigations. Ann. Rev. Entomol. 37 : 253-272.

Catts, E. P., and N. H. Haskell. 1990. Entomology and death - A procedural guide. Joyce's Print Shop, Inc., Clemson, SC.

Cragg, J. B. 1956. The olfactory behavior of Lucilia species (Diptera) under natural conditions. Ann. Appl. Biol. 44: 467-477.

Davies, L., and G. G. Rattcliffe. 1994. Development rates of some pre-adult stages in blow flies with reference to low temperatures. Med.Vet. Entomol. 8 : 245254.

Erzinclioglu, Y. Z. 1983. The application of entomology to forensic medicine. Med. Sci. Law. 23(1) : 57-63.

Fisher, R. A. 1946. A system of scoring linkage data, with special reference to the pied factors in mice. Amer. Nat. 80:568-578.

Greenberg, B. 1973. Flies and disease, vol. 2. Biology and disease transmission. Princeton University Press, Princeton, NJ.

Greenberg, B. 1990. Nocturnal oviposition behavior of blow flies (Diptera: Calliphoridae). J. Med. Entomol. 27 (5) : 807-810.

Greenberg, B. 1991. Flies as forensic indicators. J. Med. Entomol. 28 (5) : 565-577. 
Haines, C.P. and D. P. Rees. 1989. A field guide to the types of insects and mites infesting cured fish. FAO Fisheries Technical Paper No. 303. FAO, Rome.

Kasson, R. N. 1999. An experimental study of pig (Sus scrofa) carrion decomposition and arthropod succession rates with known time of death in the northern chihuahuan desert. Thesis, New Mexico State University, Las Cruces, NM.

Kirkpatrick, R. S., and J. K. Olson. 2001. Necrophagous and other associated arthropod succession on fresh and frozen pig carcasses in summer rural Central Texas. TAMU Undergrad. J. Sci. 2(3) : 17-21.

Mead, G.C. 1982. Microbiology of poultry and game birds., p. 67-101; In M. H. Brown, (eds.), Meat microbiology. Applied Science Publishers LTD., New York.

Moura, M.O., C. JB de Carvalho, and E. LA Monteiro-Filho. 1997. A preliminary analysis of insects of medico-legal importance in Curitiba, State of Parana. Mem. Inst. Oswaldo Cruz, Rio de Janeiro. 92 (2) : 269-274.

Ott, R.L., and M. Longnecker. 2001. An introduction to statistical methods and data analysis $5^{\text {th }}$ ed. Thomson Learning, Inc., New York, NY.

Romoser, W. S. and J. G. Staffolano. 1998. The science of entomology, $4^{\text {th }}$ ed. WCB/McGraw-Hill, Burr Ridge, IL.

Rosset, R. 1982. Chilling, freezing and thawing., p. 265-318; In: M. H. Brown, (ed). Meat microbiology. Applied Science Publishers Ltd., New York.

Smith, K. G. V. 1986. A manual of forensic entomology. British Museum (Natural History) London, and Cornell University Press, Ithaca, NY.

Tenorio, F. M., J. K. Olson, and C. J. Coates. 2003. Identification of three forensically important blow fly (Diptera:Calliphoridae) species in central Texas using mitochondrial DNA. J. SW. Entomol. 28(4) : 267-272.

Tessmer, J. W., C. L. Meek, and V. L. Wright. 1995. Circadian patterns of oviposition by necrophilous flies (Diptera: Calliphoridae) in southern Louisiana. SW. Entomol. 20(4) : $439-445$. 


\section{VITA}

Ryan Scott Kirkpatrick was born and raised near Waco, Texas. His permanent address where his parents, Joe and Martha Kirkpatrick, reside is 407 South Pierce Street, McGregor, Texas 76657. Upon graduating from McGregor High School in 1995, Ryan attended Texas A\&M University. In December 1999, Ryan graduated from Texas A\&M with a Bachelor of Science with a double major in animal science and entomology while serving on the Executive Council of Alpha Gamma Rho Fraternity, Beta Nu chapter.

Upon graduating, Ryan entered graduate school as a Master of Agricultural Business candidate, but soon returned to his first love, livestock entomology. Once oriented to where he felt his future lay, he along with other Texas A\&M Bonfire supporters formed the Bonfire Coalition where he served as Vice-Chair and eventually

Chair of the Bonfire Coalition. During his graduate student career, Ryan has faced many uphill battles such as funding his graduate school expenses through working two jobs, eventually acquiring a teaching assistantship.

During the 9 years spent at Texas A\&M University, Ryan has two publications in forensic entomology, an article in the Texas A\&M University Undergraduate Journal of Science and an American Academy of Forensic Science Poster Presentation in conjunction with Baylor University. Ryan also has an exhibit on forensic entomology in the Texas Ranger Hall of Fame and Museum.

This thesis marks the end of his era as a Master of Science candidate, but the future is broad and Ryan plans to work in the livestock entomology field, while exploring new horizons in forensic entomology. 